Greater Everglades Priority Ecosystem Studies Program

\title{
Observed and Modeled Mercury and Dissolved Organic Carbon Concentrations and Loads at Control Structure S-12D, Florida Everglades, 2013-17
}

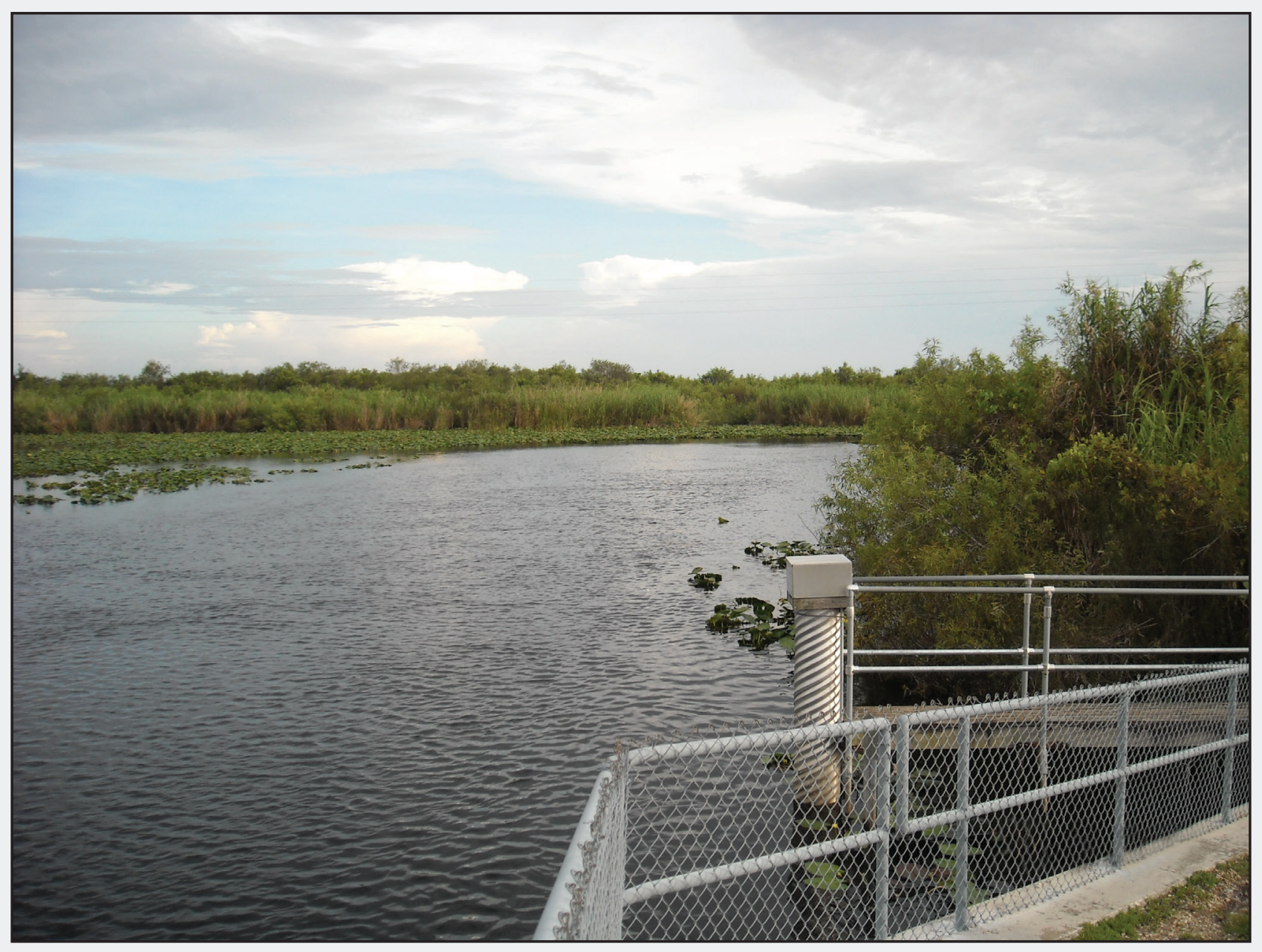

Open-File Report 2020-1092 
Cover. Photograph of U.S. Geological Survey monitoring station Tamiami Canal at S-12-D, near Miami, Florida (25454308040540), looking south downstream of S-12D structure. Photograph by Eduardo Patino, U.S. Geological Survey. 


\section{Observed and Modeled Mercury and Dissolved Organic Carbon Concentrations and Loads at Control Structure S-12D, Florida Everglades, 2013-17}

By Amanda C. Booth, Brett A. Poulin, and David P. Krabbenhoft

Greater Everglades Priority Ecosystem Studies Program

Open-File Report 2020-1092 


\title{
U.S. Department of the Interior \\ DAVID BERNHARDT, Secretary
}

\author{
U.S. Geological Survey \\ James F. Reilly II, Director
}

U.S. Geological Survey, Reston, Virginia: 2020

For more information on the USGS - the Federal source for science about the Earth, its natural and living resources, natural hazards, and the environment—visit https://www.usgs.gov or call 1-888-ASK-USGS.

For an overview of USGS information products, including maps, imagery, and publications, visit https://store.usgs.gov/.

Any use of trade, firm, or product names is for descriptive purposes only and does not imply endorsement by the U.S. Government.

Although this information product, for the most part, is in the public domain, it also may contain copyrighted materials as noted in the text. Permission to reproduce copyrighted items must be secured from the copyright owner.

Suggested citation:

Booth, A.C., Poulin, B.A., and Krabbenhoft, D.P., 2020, Observed and modeled mercury and dissolved organic carbon concentrations and loads at control structure S-12D, Florida Everglades, 2013-17: U.S. Geological Survey Open-File Report 2020-1092, 27 p., https://doi.org/10.3133/ofr20201092.

Associated data for this publication:

Booth, A.B., 2020, Calculated mercury and carbon concentrations, USGS station 254543080405401: Tamiami Canal at S-12D Near Miami, Florida, 2013-2017: U.S. Geological Survey data release, https://doi.org/10.5066/P99L01UW.

ISSN 2331-1258 (online) 


\section{Contents}

Abstract

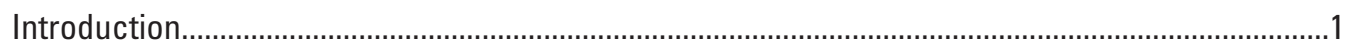

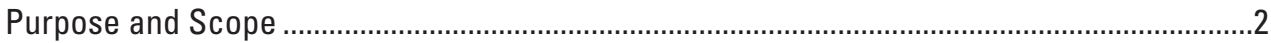

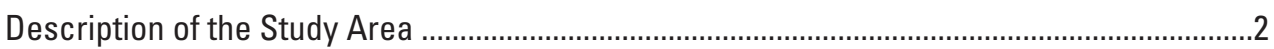

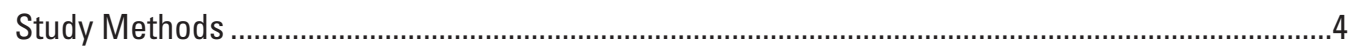

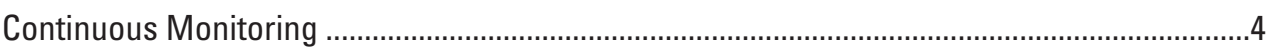

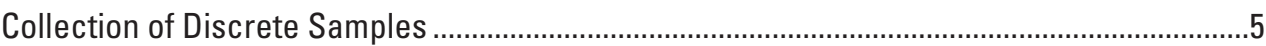

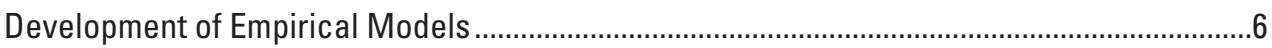

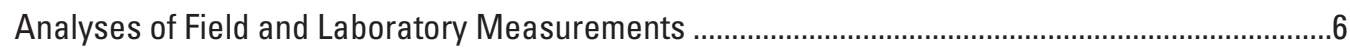

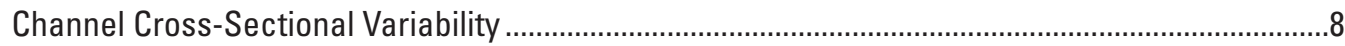

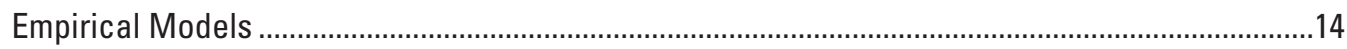

Dissolved Organic Carbon Model .........................................................................................

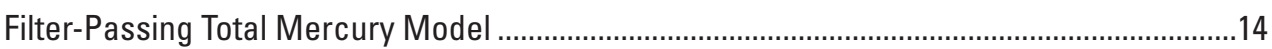

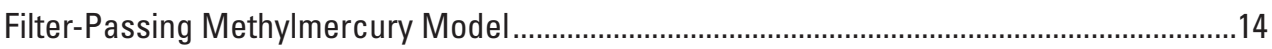

Particulate Total Mercury Model ........................................................................................14

Particulate Methylmercury Model..........................................................................................14

Dissolved Organic Carbon Concentrations and Loads.............................................................15

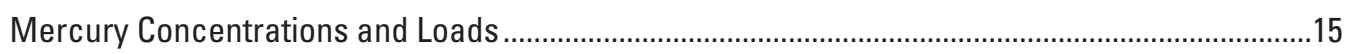

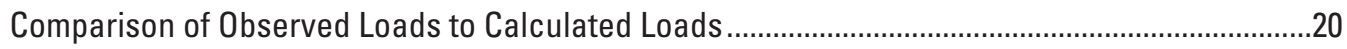

Comparison of Traditional Discrete Sampling to Surrogate Approach .............................................22

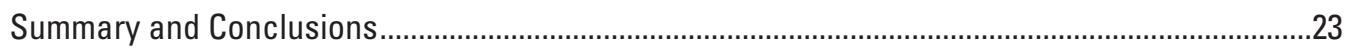

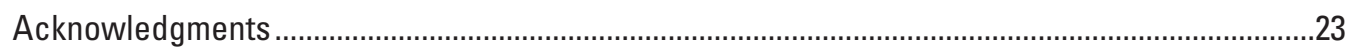

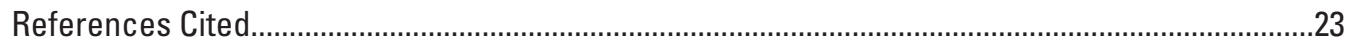

Appendixes 1-5...................................................................https://doi.org/10.3133/ofr20201092

\section{Figures}

1. Regional map showing $S-12$ control structures $A-D$ that control the flow of water from water conservation areas to Everglades National Park .................................

2. Photograph showing water-control structure S-12D .....................................................

3. Graph showing relation between temperature corrected fluorescence of chromophoric dissolved organic matter ( $\mathrm{fDOM}$ ), with the inner filter effect removed, and temperature corrected fDOM, without the inner filter effect removed

4. Graphs showing comparisons between mean cross-sectional profile data and site monitor data for temperature, specific conductance, turbidity, and fluorescence of chromophoric dissolved organic matter....

5. Graphs showing comparisons between point sample and vertically-integrated samples at point of highest flow for filter-passing total mercury, filter-passing methylmercury, particulate total mercury, and particulate methylmercury...

6. Graph showing calculated and observed concentrations of dissolved organic carbon and flow

7. Graph showing cumulative loads of dissolved organic carbon for calendar years 2014-16. 
8. Graphs showing calculated and observed filter-passing total mercury concentrations and flow, and calculated and observed filter-passing methylmercury concentrations and flow.

9. Graph showing calculated and observed concentrations of particulate total mercury and flow, and calculated and observed particulate methylmercury concentrations and flow.

10. Graph showing cumulative loads of total mercury for 2014-16 calendar years.............19

11. Graph showing cumulative loads of methylmercury for calendar years 2014-16...........19

12. Graphs showing comparisons between 1-minute loads calculated using observed concentrations and calculated concentrations

13. Graphs showing annual loads of mercury separated into fractions including particulate methylmercury, particulate inorganic divalent mercury, filter-passing methylmercury, and filter-passing inorganic divalent mercurycalculated by the surrogate model approach and calculated using only observed samples

\section{Tables}

1. Maximum and minimum sensor values recorded during sampling events, and the maximum and minimum overall sensor data values recorded during the study period at $\mathrm{S}-12 \mathrm{D}$

2. Number of observations, minimum, maximum, and mean concentrations of observed dissolved organic carbon, decadic absorption coefficient at 254 nanometers, specific ultraviolet absorbance at 254 nanometers, specific conductance, fluorescence of chromophoric dissolved organic matter, temperature, turbidity, and flow data collected at S-12D from September 2013 to December 2016

3. Pearson correlation coefficients of observed dissolved organic carbon, decadic absorption coefficient at 254 nanometers, specific ultraviolet absorbance at 254 nanometers, specific conductance, fluorescence of chromophoric dissolved organic matter, temperature, turbidity, and flow data collected at S-12D from September 2013 to December 2016

4. Number of observations, minimum, maximum, and mean concentrations of observed filter-passing total mercury and methylmercury, particulate total mercury and methylmercury, dissolved organic carbon, decadic absorption coefficient at 254 nanometers, specific ultraviolet absorbance at 254 nanometers, specific conductance, fluorescence of chromophoric dissolved organic matter, temperature, turbidity, and flow data collected at S-12D from September 2013 to December 2016

5. Pearson correlation coefficients of observed filter-passing total mercury and methylmercury, particulate total mercury and methylmercury, dissolved organic carbon, decadic absorption coefficient at 254 nanometers, specific ultraviolet absorbance at 254 nanometers, specific conductance, fluorescence of chromophoric dissolved organic matter, temperature, turbidity, and flow data collected at S-12D from September 2013 to December 2016.

6. Coefficient of determination, model standard error, and relative model bias for concentration models and calculated versus observed loads of dissolved organic carbon, filter-passing total mercury and methylmercury, particulate total mercury and methylmercury... 


\section{Conversion Factors}

U.S. customary units to International System of Units

\begin{tabular}{|c|c|c|}
\hline Multiply & By & To obtain \\
\hline \multicolumn{3}{|c|}{ Length } \\
\hline inch (in.) & $2.54 \times 10^{7}$ & nanometer (nm) \\
\hline inch (in) & $2.54 \times 10^{4}$ & micrometer $(\mu \mathrm{m})$ \\
\hline inch (in) & 25.4 & centimeter $(\mathrm{cm})$ \\
\hline foot $(\mathrm{ft})$ & 0.3048 & meter $(\mathrm{m})$ \\
\hline mile (mi) & 1.609 & kilometer (km) \\
\hline \multicolumn{3}{|c|}{ Volume } \\
\hline cubic foot $\left(\mathrm{ft}^{3}\right)$ & 28.32 & cubic decimeter $\left(\mathrm{dm}^{3}\right)$ \\
\hline cubic foot $\left(\mathrm{ft}^{3}\right)$ & 0.02832 & cubic meter $\left(\mathrm{m}^{3}\right)$ \\
\hline cubic inch (in. ${ }^{3}$ ) & 0.01639 & liter (L) \\
\hline \multicolumn{3}{|c|}{ Flow rate } \\
\hline cubic foot per second $(\mathrm{ft} 3 / \mathrm{s})$ & 0.02832 & cubic meter per second $\left(\mathrm{m}^{3} / \mathrm{s}\right)$ \\
\hline \multicolumn{3}{|c|}{ Mass } \\
\hline ton, short $(2,000 \mathrm{lb})$ & 0.9072 & metric ton $(\mathrm{t})$ \\
\hline ton per day (ton/d) & 0.9072 & metric ton per day $(\mathrm{t} / \mathrm{d})$ \\
\hline ton per year (ton/yr) & 0.9072 & metric ton per year $(\mathrm{t} / \mathrm{yr})$ \\
\hline
\end{tabular}

Temperature in degrees Celsius $\left({ }^{\circ} \mathrm{C}\right)$ may be converted to degrees Fahrenheit ( ${ }^{\circ} \mathrm{F}$ ) as follows: ${ }^{\circ} \mathrm{F}$ $=\left(1.8 \times{ }^{\circ} \mathrm{C}\right)+32$.

Temperature in degrees Fahrenheit $\left({ }^{\circ} \mathrm{F}\right)$ may be converted to degrees Celsius $\left({ }^{\circ} \mathrm{C}\right)$ as follows: ${ }^{\circ} \mathrm{C}$ $=\left({ }^{\circ} \mathrm{F}-32\right) / 1.8$.

\section{Datum}

Vertical coordinate information is referenced to the National Geodetic Vertical Datum of 1929 (NGVD 29).

Elevation, as used in this report, refers to distance above the vertical datum.

\section{Supplemental Information}

Specific conductance is given in microsiemens per centimeter at 25 degrees Celsius $(\mu \mathrm{S} / \mathrm{cm}$ at $\left.25^{\circ} \mathrm{C}\right)$.

Concentrations of chemical constituents in water are given in either milligrams per liter (mg/L) or nanograms per liter (ng/L). 


\title{
Abbreviations
}

\author{
$\alpha_{254}$ decadic absorption coefficient at 254 nanometers \\ DOC dissolved organic carbon \\ EPA U.S. Environmental Protection Agency \\ fDOM fluorescence of chromophoric dissolved organic matter \\ $\mathrm{FHg}(\mathrm{II}) \mathrm{i}$ filter-passing inorganic divalent mercury \\ FMeHg filter-passing methylmercury \\ FNU formazin nephelometric unit \\ FTHg filter-passing total mercury \\ $\mathrm{Hg} \quad$ mercury \\ $\mathrm{Hg}(\mathrm{II}) \mathrm{i}$ inorganic divalent mercury \\ $\mathrm{MeHg}$ methylmercury \\ MSPE average model standard percentage error \\ NWIS National Water Information System \\ NWOL National Water Quality Laboratory \\ $\mathrm{PHg}(\mathrm{II}) \mathrm{i}$ particulate inorganic divalent mercury \\ PMeHg particulate methylmercury \\ PTHg particulate total mercury \\ QSE quinine sulfate equivalent \\ $r \quad$ pearson correlation coefficient \\ $\mathrm{R}^{2} \quad$ coefficient of determination \\ RMSE root mean square error \\ SAID Surrogate Analysis and Index Developer \\ SC specific conductance \\ SUVA $_{254}$ specific ultraviolet absorbance at 254 nanometers \\ $\mathrm{THg}$ total mercury \\ USGS U.S. Geological Survey
}




\title{
Observed and Modeled Mercury and Dissolved Organic Carbon Concentrations and Loads at Control Structure S-12D, Florida Everglades, 2013-17
}

\author{
By Amanda C. Booth, Brett A. Poulin, and David P. Krabbenhoft
}

\section{Abstract}

Mercury (Hg) has been a contaminant of concern for several decades in South Florida, particularly in the Florida Everglades. The transport and bioavailability of $\mathrm{Hg}$ in aquatic systems is intimately linked to dissolved organic carbon (DOC). In aquatic systems, $\mathrm{Hg}$ can be converted to methylmercury $(\mathrm{MeHg})$, which is the form of $\mathrm{Hg}$ that bioaccumulates in food webs. The bioaccumulation of $\mathrm{MeHg}$ poses significant health risks to wildlife and humans. Fish consumption advisories triggered by elevated Hg levels first appeared in the 1980s in South Florida. Multiple structures regulate freshwater distribution to Everglades National Park, including S-12D. This report summarizes seasonal and annual concentration and load data from late September 2013 to April 2017 for the total of (1) filter-passing total mercury (FTHg), (2) filter-passing methylmercury (FMeHg), (3) particulate total mercury (PTHg),

(4) particulate methylmercury (PMeHg) and, (5) DOC

discharged through control structure S-12D. The loads of $\mathrm{Hg}$ fractions and DOC at control structure S-12D were determined by pairing discharge data with constituent concentrations estimated by empirical models based on surrogate in situ water quality measurements.

Calculated concentrations of DOC ranged from 12.8 milligrams per liter $(\mathrm{mg} / \mathrm{L})$ to $27.9 \mathrm{mg} / \mathrm{L}$ with a mean of $18.8 \mathrm{mg} / \mathrm{L}$ during the study period. Annual loads of DOC ranged from 3,950 tons in 2015 to 10,900 tons in 2016. DOC loads increased linearly with an increase in flow, and the highest monthly DOC load of 1,630 tons was observed in February 2016.

Calculated concentrations of FTHg ranged from 0.35 to 1.55 nanograms per liter (ng/L) with a mean of $0.85 \mathrm{ng} / \mathrm{L}$ during the study period. Calculated concentrations of FMeHg ranged from $0.06 \mathrm{ng} / \mathrm{L}$ to $0.24 \mathrm{ng} / \mathrm{L}$ with a mean of $0.14 \mathrm{ng} / \mathrm{L}$ during the study period. Generally, FTHg and FMeHg concentrations were lower during periods of decreased flow and higher during periods of increased flow. Calculated PTHg concentrations ranged from $0.09 \mathrm{ng} / \mathrm{L}$ to $4.19 \mathrm{ng} / \mathrm{L}$ with a mean of $0.58 \mathrm{ng} / \mathrm{L}$ during the study period. Calculated $\mathrm{PMeHg}$ concentrations ranged from below the limit of detection $<0.01 \mathrm{ng} / \mathrm{L}$ to $0.29 \mathrm{ng} / \mathrm{L}$ with a mean of $0.03 \mathrm{ng} / \mathrm{L}$ during the study period.
Loads of $\mathrm{Hg}$ were often zero or lowest from November to May, owing to the lack of flow or low-flow conditions. FTHg and $\mathrm{FMeHg}$ loads increased linearly with an increase in flow and typically were highest from June to October. During periods of increasing flow or following changes in gate operations, $\mathrm{PTHg}$ and $\mathrm{PMeHg}$ constituted a greater percentage of the total $\mathrm{Hg}$ load. Annual loads of total Hg (filter-passing and particulate) ranged from 254 grams in 2015 to 658 grams in 2016. FTHg was the predominant contributor to the total Hg load. Information presented herein provides the first assessment of DOC and Hg loads to Everglades National Park through control structure S-12D using continuous in situ measurements of discharge and constituent surrogates and compares the surrogate model approach to loads calculated from monthly sampling. Analysis of calculated and observed loads demonstrates the significance of flow data on calculating constituent loads.

\section{Introduction}

Elevated levels of mercury (Hg) have long been a concern in the Florida Everglades. Fish consumption advisories issued in response to $\mathrm{Hg}$ contamination first appeared in South Florida in the 1980s. The predominant source of the Hg is wet deposition (Guentzel and others, 1995; Axelrad and others, 2009; Coburn and others, 2016). While the emission of $\mathrm{Hg}$ in the United States has decreased by approximately 60 percent since 1990 (Wentz and others, 2014), fish consumption advisories in response to elevated concentrations of methylmercury (MeHg) still exist in many places throughout the country, including South Florida. MeHg bioaccumulates in organisms at the base of the aquatic food web and biomagnifies upward through trophic levels (Mason and others, 1996), posing major health risks to both humans and wildlife. $\mathrm{Hg}$ can adversely affect the cardiovascular, pulmonary, digestive, renal, immune, nervous, endocrine, and reproductive systems in humans (Rice and others, 2014).

In aquatic systems, anaerobic microorganisms can convert inorganic divalent mercury $(\mathrm{Hg}[\mathrm{II}] \mathrm{i})$ to $\mathrm{MeHg}$ (Gilmour and others, 2013), which is the form of $\mathrm{Hg}$ that bioaccumulates in food webs. The production of $\mathrm{MeHg}$ from $\mathrm{Hg}(\mathrm{II}) \mathrm{i}$ 
varies spatially and temporally in the greater Everglades ecosystem and is influenced by temperature, oxygen levels, organic carbon, and sulfate (Aiken and others, 2011; Orem and others, 2011). Favorable conditions for the conversion of $\mathrm{Hg}(\mathrm{II}) \mathrm{i}$ to $\mathrm{MeHg}$ include lower dissolved oxygen concentration, higher concentrations of dissolved organic carbon (DOC) and sulfate, and higher temperatures (Wentz and others, 2014). Furthermore, wetting and drying of wetland sediments can also increase $\mathrm{Hg}(\mathrm{II}) \mathrm{i}$ methylation because of the oxidation of peat and subsequent release of sulfate upon rewetting (Wentz and others, 2014). Within Everglades National Park, a strong spatial dependence is observed in the concentration of $\mathrm{MeHg}$ in the aquatic food web (Rumbold and others, 2018), but questions remain regarding the processes controlling $\mathrm{Hg}$ delivery to the park.

The delivery of $\mathrm{Hg}$ and DOC to Everglades National Park is of keen interest, because $\mathrm{MeHg}$ can bioaccumulate in fish and $\mathrm{Hg}(\mathrm{II}) \mathrm{i}$ can be converted to $\mathrm{MeHg}$ within the park's marshlands. Furthermore, this region of the Everglades ecosystem is an important conduit between the freshwater marshlands and tidal wetlands. Aside from influencing the transport and bioavailability of $\mathrm{Hg}$, DOC can influence $\mathrm{pH}$ and controls several additional aquatic processes important to ecosystem health, including light penetration, and transport of hydrophobic compounds such as pesticides (Aiken and others, 2011). Previous studies demonstrated that measurements of fluorescence of chromophoric dissolved organic matter (fDOM) can be used to estimate concentrations of filter-passing total $\mathrm{Hg}$ (FTHg), filter-passing MeHg (FMeHg), and DOC in surface water, allowing for the computation of continuous timeseries data of concentrations (Bergamaschi and others, 2011; Bergamaschi and others, 2012a, Bergamaschi and others, 2012b). Other studies have documented relations between suspended sediment and particulate Hg concentrations (Schoellhamer and others, 2007; Horowitz, 2009; Etheridge, 2015). This report builds on previous studies by using fDOM to predict filter-passing constituents (FTHg, FMeHg, DOC) and turbidity data to estimate particulate total $\mathrm{Hg}(\mathrm{PTHg})$ and particulate $\mathrm{MeHg}(\mathrm{PMeHg})$ concentrations. Concentration data coupled with concurrent flow data were used to quantify constituent loads.

This study, conducted by the U.S. Geological Survey (USGS) as part of the Greater Everglades Priority Ecosystem Studies Program, developed site-specific surrogate models for calculating the concentrations and loads of $\mathrm{Hg}$ fractions (FTHg, FMeHg, PTHg, PMeHg) and DOC within flows passing through control structure S-12D. This report provides the first multiyear assessment of DOC and $\mathrm{Hg}$ loads to Everglades National Park through control structure S-12D using continuous in situ measurements (15-minute intervals). Long-term, continuous data can be used to describe the seasonal and annual variability of constituent concentrations, inform the understanding of $\mathrm{Hg}$ cycling and transport mechanisms within the greater Everglades landscape, and potentially provide insights into the effects of restoration efforts on Hg cycling.

\section{Purpose and Scope}

The primary purpose of this report is to summarize seasonal and annual concentration and load data from late September 2013 to early April 2017 for total Hg and MeHg concentrations (filter-passing and particulate fractions) and DOC at control structure S-12D. In addition, the report uses in situ data to document the development of site-specific surrogate models for quantification of total $\mathrm{Hg}$ and $\mathrm{MeHg}$ concentrations (filter-passing and particulate) and DOC. Data on flow, specific conductance (SC), temperature, turbidity, and fDOM were used to compute constituent concentrations and loads. All surrogate and discrete data used in the analyses are available in the USGS National Water Information System (NWIS) database (U.S. Geological Survey, 2019). Model archive summaries for each of the five models are described within the text and additional information is available in the appendixes. The 15-minute interval concentration data calculated from the models are provided by Booth (2020). Additionally, loads calculated using surrogate methods were compared to loads calculated using only observed concentrations.

\section{Description of the Study Area}

The construction of Tamiami Trail (U.S. 41) in the late 1920s changed the natural freshwater flow to what is now Everglades National Park. To manage the flow of freshwater to the park, several control structures (pumps, gates, and culverts) were constructed. S-12D is one of several structures regulating freshwater flow from Water Conservation Area 3A and L-67 south to Everglades National Park (fig. 1). Water from Water Conservation Area 3A is released to the Shark River Slough in the park through the S-12 and S-333 structures. Water conservation areas were created to (1) provide flood control; (2) provide water for agricultural, municipal, and industrial uses, and for Everglades National Park; (3) enhance conditions favorable for groundwater recharge; (4) reduce saltwater intrusion; and (5) benefit Everglades wildlife and recreation. Historically, S-12D (fig. 2) has delivered 40 percent of the flow through the S-12 structures, and structures S-12A, S-12B, and S-12C have delivered 10, 20, and 30 percent, respectively, of the total flow (U.S. Army Corps of Engineers, 2012). Restoration efforts are currently (2020) underway to mitigate many unintended water-related consequences of the Tamiami Trail (U.S. 41), including the construction of bridges to allow for improved hydrologic connectivity and water delivery schedules.

S-12D is on Tamiami Trail (U.S. 41), approximately 30 miles (mi) west of Miami, 25-30 mi northeast of the tidal creeks of Everglades National Park, and $50 \mathrm{mi}$ due north of Florida Bay (figs. 1 and 2). The S-12D structure consists of six vertical-lift gates designed to release freshwater at selected flow rates, controlled by the height of the gate openings. The four S-12 structures (S-12A, S-12B, S-12C, and S-12D) were designed to discharge a maximum of 32,000 cubic feet per 


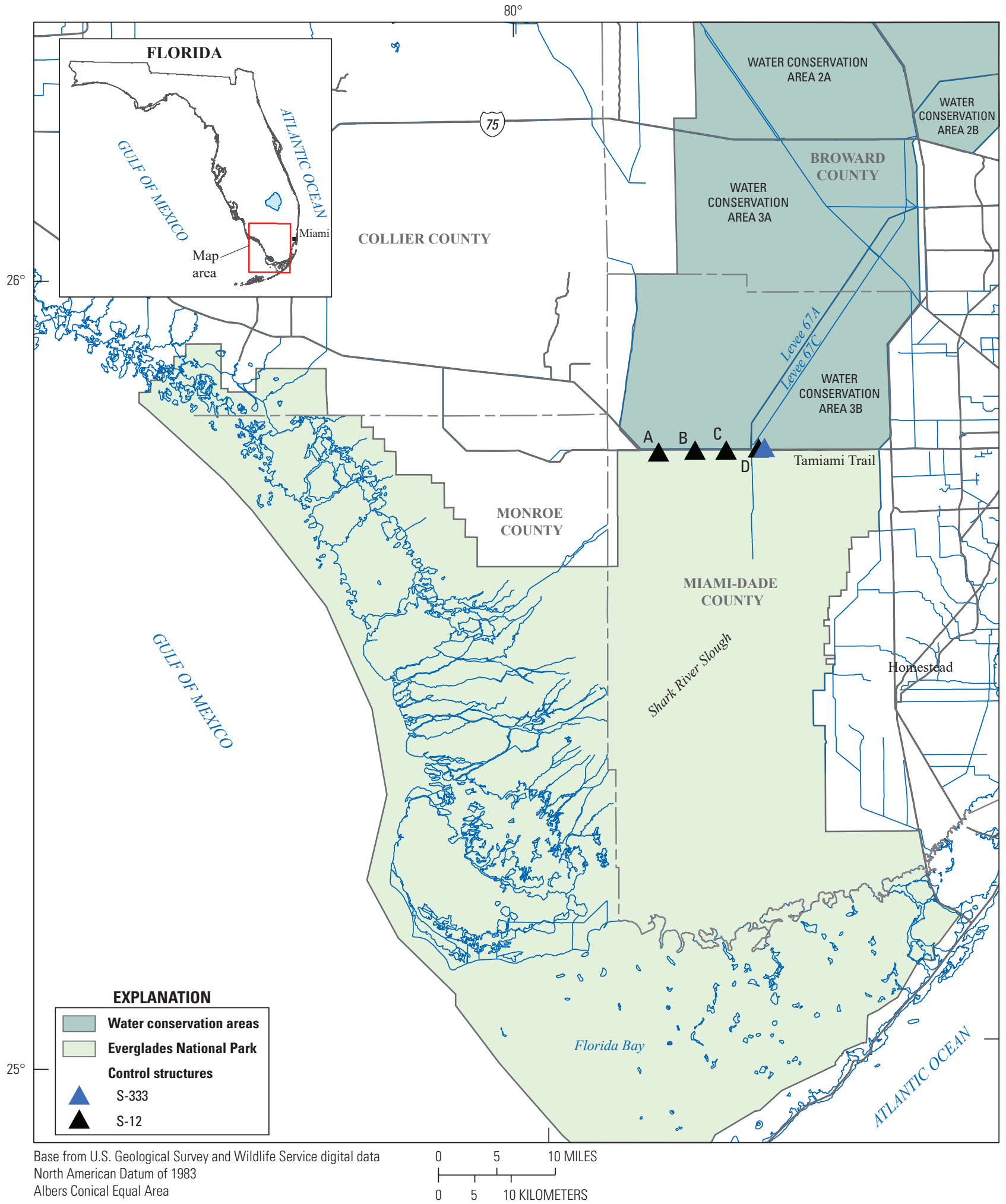

Figure 1. S-12 control structures $A-D$ that control the flow of water from water conservation areas to Everglades National Park. 


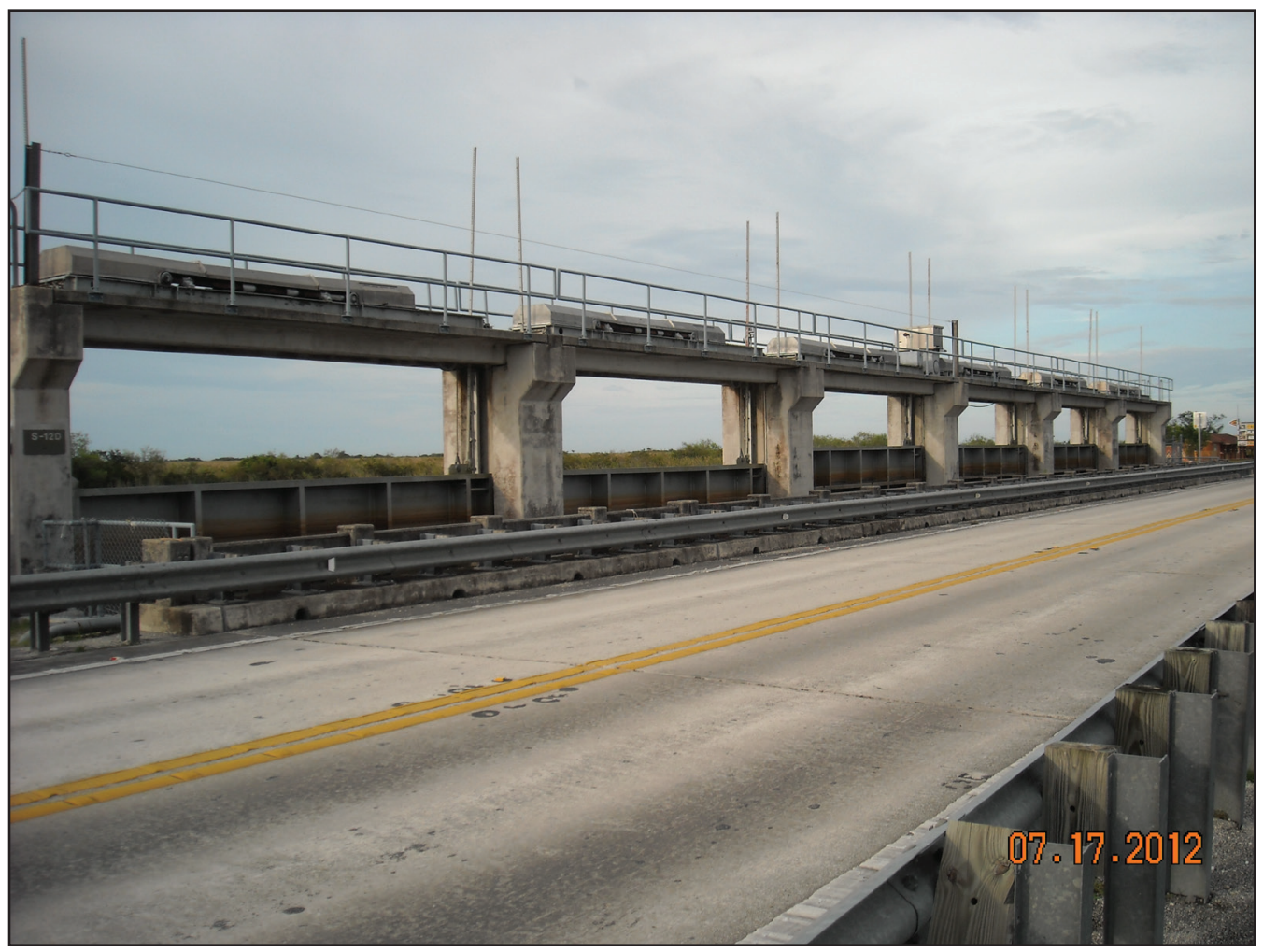

Figure 2. Water-control structure S-12D. Photograph by Eduardo Patino, U.S. Geological Survey.

second $(\mathrm{ft} 3 / \mathrm{s})$ combined; however, sedimentation and vegetation accumulation have decreased the capacity of the structures. No minimum discharge through the S-12 structures is required, but typically S-12A is closed from November 1 to July 14 and S-12B is closed from January 1 to July 14.

\section{Study Methods}

Various methods and procedures were followed to collect and analyze the data used to develop the empirical models to simulate concentrations and calculate loads of $\mathrm{Hg}$ and DOC at control structure S-12D. The study site, S-12D, was chosen because it typically has the highest flow volume of the S-12 structures. Upstream and downstream water levels, flow volume, and several types of water-quality data were collected at the structure on a continuous (15-minute interval) basis. The water-quality data included measurements of specific conductance, temperature, turbidity, and fDOM. Data were transmitted hourly through the Geostationary Operational Environmental Satellite system and made available to the public on a near real-time basis. Discrete water samples for laboratory analyses of $\mathrm{Hg}$ and $\mathrm{DOC}$ were collected monthly from September 2013 to February 2017. Development of the models was guided by procedures described in Rasmussen and others (2009).

\section{Continuous Monitoring}

Water levels were continuously recorded at points just upstream (headwater) and downstream (tailwater) of the water-control structure, following USGS procedures outlined in Sauer and Turnipseed (2010). The magnitude of flow at S-12D, which was controlled by the height of the gate openings, was computed using one of two methods: (1) a submerged-orifice equation was applied when the gates were in the water, or (2) a stage-discharge rating was applied when the gates were out of the water. Both computation methods were developed and verified on the basis of historical discharge measurements made twice a month when water was flowing through the S-12D structure (Rantz and others, 1982; Sanders and Feaster, 2004). During this study period, discharge measurements were made with an acoustic Doppler current profiler twice a month to verify structure calibration ratings.

Water-quality data were collected by sensors in a YSI EXO multiparameter monitoring system from September 2013 to April 2017 at a fixed point in the middle of the water column, at an elevation of approximately $4.7 \mathrm{ft}$ above NGVD 29 and near the west bank of the downstream pool of S-12D. Measurements included those for specific conductance, in microsiemens per centimeter at 25 degrees Celsius $(\mu \mathrm{S} / \mathrm{cm}$ at $\left.25{ }^{\circ} \mathrm{C}\right)$; temperature, in degrees Celsius $\left({ }^{\circ} \mathrm{C}\right)$; turbidity, in formazin nephelometric units (FNU); and fDOM, in quinine 
sulfate equivalents (QSE), the concentration of quinine sulfate dehydrate in parts per billion that results in an equivalent instrument response. The YSI EXO sensors were inspected for fouling approximately every 4 weeks, and calibration verifications were made every 8 weeks. Drift and fouling corrections were determined and applied using formulas provided in Wagner and others (2006).

fDOM data were corrected for temperature, turbidity, and inner filter effects as described in Downing and others (2012). The correction of fDOM for turbidity assumed the attenuation of light by International Humic Substances Society Elliot silt loam soil. Serial dilutions were performed to determine the inner filter effect using Caloosahatchee River water collected at S-79 (USGS site number 02292900; filtered at 0.45 micrometer $(\mu \mathrm{m})$ on August 16,2017$)$ to span the range of fDOM measurements observed at S-12D during the study period. Data collected at S-12D on September 28, 2017, indicated that the Caloosahatchee water was representative of S-12D with respect to the inner filter effect (fig. 3).

Vertical profiles of water-quality sensor data were recorded across the sampling section to define vertical and horizontal stratification. Parameters recorded in the vertical profiles were the same as those for the site monitor sensor. At S-12D, measurements were made in vertical profiles at six locations in front of the midsection of each gate; the first location matched the location where the site monitoring sensors were deployed. The data collected during measurements in the six vertical profiles were averaged to represent the mean channel conditions at the time of sampling. To ensure comparability between cross-sectional profiles and continuous site monitor readings, the same calibration verifications were used for the profile sensors and site monitor sensors. Raw fDOM values were used for comparison (that is, without correcting fDOM measurements for temperature, turbidity, or inner filter effect). The purpose of these raw fDOM data comparisons was to verify that continuous fDOM measurements at a single location of S-12D were representative of the entire channel.

\section{Collection of Discrete Samples}

All equipment used for the collection and transport of water samples for analysis of $\mathrm{Hg}$ was precleaned by the USGS Mercury Research Laboratory in Middleton, Wisconsin. Samples were collected using a USGS DH-81 sampler attached to a $1 / 2$-inch-diameter wading rod. The DH-81 was configured with a US-D-95 cap, a nozzle, and a 1-liter bottle all made of polytetrafluoroethylene (Davis, 2005). Initially, two water samples were collected for Hg analysis: a point sample adjacent to the YSI EXO sensors and a single vertically

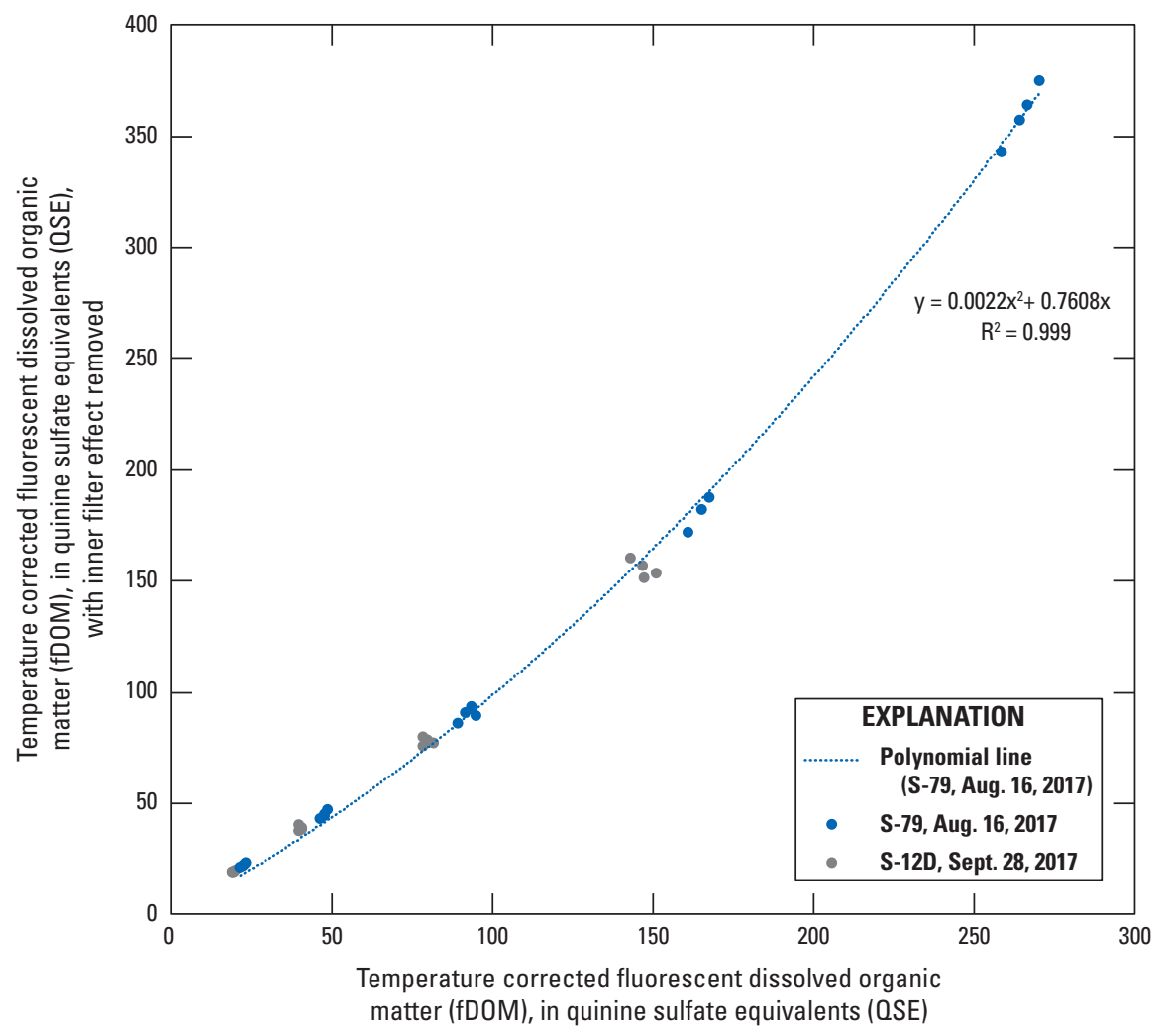

Figure 3. Relation between temperature corrected fluorescence of chromophoric dissolved organic matter (fDOM), with the inner filter effect removed, and temperature corrected fDOM, without the inner filter effect removed. The dashed blue line is the fit of all data using a second-order polynomial function. 
Observed and modeled mercury and dissolved organic carbon concentrations and loads at control structure S-12D

integrated sample at the location of highest water velocity. Samples were placed on ice for transportation from the field to the processing laboratory, passed through a $0.7-\mu \mathrm{m}$ quartz fiber filter to separate filter-passing and particulate $\mathrm{Hg}$ fractions, and shipped to the USGS Mercury Research Laboratory within 24 hours. Particulate samples were shipped on dry ice. Filtered waters were acidified to 1 percent volume-to-volume with concentrated ultraclean hydrochloric acid within 5 hours of collection and were stored and shipped in coolers at room temperature (U.S. Geological Survey, variously dated).

Samples were analyzed for total and methylmercury (filter-passing and particulate) at the USGS Mercury Research Laboratory. Laboratory personnel processed samples using techniques and methods documented in U.S. Environmental Protection Agency (EPA) Method 1631 (U.S. Environmental Protection Agency, 2002), DeWild and others (2002, 2004), and Olund and others (2004).

Surface-water samples for analyses of DOC, decadic absorption coefficient at 254 nanometers $(\mathrm{nm})\left(\alpha_{254}\right)$, and specific ultraviolet absorbance at $254 \mathrm{~nm}\left(\mathrm{SUVA}_{254}\right)$ (Weishaar and others, 2003) were collected adjacent to the YSI EXO sensors in the same manner as the Hg samples. The $\mathrm{SUVA}_{254}$ was calculated by dividing the $\alpha_{254}$ by DOC concentration and is reported in units of liters per milligram carbon per meter (Weishaar and others, 2003). Samples were filtered through a $0.45-\mu \mathrm{m}$ capsule filter into amber glass 2-liter bottles within 15 minutes of being collected and were stored immediately on ice. Samples for $\alpha_{254}$ measurement were analyzed at the USGS Organic Carbon Migration in Aquatic Environments, Project Laboratories Branch in Boulder, Colorado, using a spectrophotometer and a 1-centimeter quartz cuvette; sample spectra were measured with respect to a blank spectrum containing high-purity water. Samples were analyzed for DOC by wet chemical oxidation (Aiken, 1992) at the USGS Laboratory in Boulder, Colo., between September 2013 and September 2016. Samples collected between October 2016 and February 2017 were analyzed by high-temperature catalytic combustion at the USGS National Water Quality Laboratory (NWQL) in Denver, Colo. (Clescrei and others, 1998). Samples were collected and analyzed by both the USGS laboratory in Boulder and the NWQL on six instances (February 2, May 23, June 20, July 18, August 16, and September 19, 2016). Relative percent differences in DOC concentration from the split-sample analyses at the two laboratories ranged from -1.1 to 10.2 percent, with an average of 4.3 percent $(n=6)$. Although the results from the NWQL were slightly lower on average than those reported from the Boulder laboratory, the analyses from both laboratories were included in model development. For instances in which multiple samples were collected in a single day, the analysis for the first sample collected was the sole analysis used in model development, regardless of which laboratory analyzed the sample.

\section{Development of Empirical Models}

Five site-specific empirical models were developed to calculate concentrations of filter-passing and particulate total $\mathrm{Hg}$ and $\mathrm{MeHg}$ and DOC at control structure S-12D. Microsoft Excel and the USGS Surrogate Analysis and Index Developer
(SAID) tool (Domanski and others, 2015) were used to make regression analyses of the concentrations for each constituent. Model archive summaries for each constituent are available in the appendixes. The distribution of residuals was examined for normality, and plots of residuals (the difference between the observed and calculated values) were examined for homoscedasticity (equal variance). In short, models were selected on the basis of residual plots, relatively high coefficient of determination $\left(\mathrm{R}^{2}\right)$, and root mean square error (RMSE).

To develop empirical models for estimating long-term records of $\mathrm{Hg}$ and carbon concentrations that are comparable across sites and over time, instrument characteristics and site-specific environmental conditions need to be considered and multiple linear regressions employed (Rasmussen and others, 2009). The abbreviation fDOM refers to the fraction of chromophoric dissolved organic matter that fluoresces and is commonly used as a surrogate for DOC concentration (Spencer and others, 2007; Bergamaschi and others, 2012b; Pellerin and others, 2012). The use of specific conductance as a surrogate for DOC is also supported by the work of Curtis and Adams (1995) and that of Monteiro and others (2014). Temperature also was explored as a variable in all models to account for seasonal variability. Turbidity data were used as a proxy for particulate $\mathrm{Hg}$ concentration, applying documented techniques and methods on the use of turbidity for computing suspended sediment concentrations (Rasmussen and others, 2009). The accuracy of these models is highly dependent on the range of variables used in their development and whether predictive variables are appropriately extrapolated when recorded values exceed those used in model development.

\section{Analyses of Field and Laboratory Measurements}

Large temporal variations in in situ measurements were observed at S-12D during the study period. Temperatures ranged from $15.9^{\circ} \mathrm{C}$ on January 25,2016 , to $32.4{ }^{\circ} \mathrm{C}$ on August 25, 2015, and July 30, 2016. The values of fDOM ranged from 79.9 QSE on February 14, 2014, to 610.5 QSE on August 1, 2014. Specific conductance ranged from $260 \mu \mathrm{S} / \mathrm{cm}$ at $25^{\circ} \mathrm{C}$ on June 27,2013 , to $916 \mu \mathrm{S} / \mathrm{cm}$ at $25^{\circ} \mathrm{C}$ on September 22, 2015. Turbidity values ranged from zero FNU on several days throughout 2013 to $87 \mathrm{FNU}$ on December 10, 2014. The maximum and minimum sensor data values recorded during model development and during the entire study period are presented in table 1 .

Notably, the turbidity values used in development of the models ranged from 0.2 to $16.0 \mathrm{FNU}$ (values measured during a sampling event), whereas the maximum recorded (sensor) value during the study period was $87.0 \mathrm{FNU}$. As is evident in recorded field data, periods of elevated turbidity were uncommon and of short duration (usually lasting less than 30 minutes). For example, daily mean values of turbidity for days when elevated turbidity was observed never exceeded $10 \mathrm{FNU}$. All recorded turbidity values greater than $30 \mathrm{FNU}$ were excluded from the calculations. The effect of the 
Table 1. Maximum and minimum sensor values recorded during sampling events, and the maximum and minimum overall sensor data values recorded during the study period at S-12D.

\begin{tabular}{lcc}
\hline \multicolumn{1}{c}{ Data descriptor } & $\begin{array}{c}\text { Recorded during a sampling } \\
\text { event and used in model } \\
\text { development }\end{array}$ & $\begin{array}{c}\text { Recorded at S-12D during } \\
\text { the study period }\end{array}$ \\
\hline Minimum turbidity (formazin nephelometric units) & 0.2 & 0.0 \\
Maximum turbidity (formazin nephelometric units) & 16 & 87 \\
Minimum temperature (degrees Celsius) & 18.2 & 15.9 \\
Maximum temperature (degrees Celsius) & 30.4 & 32.4 \\
Minimum specific conductance (microsiemens per centimeter at 25 degrees & 366 & 260 \\
$\quad$ Celsius) & 796 & 916 \\
Maximum specific conductance (microsiemens per centimeter at 25 degrees & 118 & 80 \\
$\quad$ Celsius) & 538 & 611 \\
Minimum fDOM (quinine sulfate equivalents) & & \\
Maximum fDOM (quinine sulfate equivalents) & & \\
\hline
\end{tabular}

exclusion of values greater than $30 \mathrm{FNU}$ on empirical models is considered negligible because of the low frequency of elevated turbidity measurements and the short duration of such periods of elevated turbidity. Samples containing elevated levels of turbidity were very rare at this site over the study duration and commonly were those collected immediately after a gate of the S-12D structure was opened. In an effort to capture a wide range of conditions for model calibration, a discrete sampling event was conducted on September 23, 2015, immediately after the gates of the S-12D structure were opened. Samples were collected on this date at 8:02 a.m., 8:19 a.m., and 9:41 a.m. eastern standard time. Because of the similarity in the laboratory-determined values and the field sensor data for the 8:02 a.m. and 8:19 a.m. samples, only the 8:02 a.m. sample was used in model development. The measurement collected at 9:41 a.m. eastern standard time was included in model development because there was a substantive change in field sensor data. This sample also had the highest turbidity of any sample collected (16 FNU).

Observed DOC concentrations ranged from $13.4 \mathrm{mg} / \mathrm{L}$ on July 18, 2016, to $25.8 \mathrm{mg} / \mathrm{L}$ on August 6, 2014 (table 2). These concentrations were highly correlated (Pearson correlation coefficient [r] greater than 0.8 ) with $\alpha_{254}$, specific conductance, and fDOM. Observed DOC concentration, however, was not strongly correlated with temperature, turbidity, or flow (r less than 0.2). Table 3 presents the $r$ values and the number of observations, minimum, maximum, and mean values.

Table 2. Number of observations, minimum, maximum, and mean concentrations of observed dissolved organic carbon (DOC), decadic absorption coefficient at 254 nanometers $\left(\alpha_{254}\right)$, specific ultraviolet absorbance at 254 nanometers $\left(S U V A_{254}\right)$, specific conductance, fluorescence of chromophoric dissolved organic matter (fDOM), temperature, turbidity, and flow data collected at S-12D from September 2013 to December 2016.

\begin{tabular}{lcccc}
\hline \multicolumn{1}{c}{ Data descriptor } & Observations & Minimum & Maximum & Mean \\
\hline $\begin{array}{l}\text { Dissolved organic carbon (milli- } \\
\text { grams per liter) }\end{array}$ & 31 & 13.4 & 25.8 & 19.1 \\
$\begin{array}{l}\text { Decadic absorption coefficient at } \\
\quad 254 \text { nanometers, } \alpha_{254}\end{array}$ & 30 & 0.34 & 0.78 & 0.55 \\
$\begin{array}{l}\text { SUVA } 254 \text { (liters per milligram car- } \\
\text { bon per meter) }\end{array}$ & 30 & 2.2 & 3.5 & 2.9 \\
$\begin{array}{l}\text { Specific conductance (microsiemens } \\
\text { per centimeter at } 25 \text { degrees }\end{array}$ & 31 & 366 & 796 & 541 \\
$\quad$ Celsius) & & & & 289 \\
fDOM (quinine sulfate equivalent) & 31 & 119 & 538 & 25.8 \\
$\begin{array}{l}\text { Temperature (degrees Celsius) } \\
\text { Turbidity (formazin nephelometric }\end{array} \quad 18.2$ & 30.4 & 1.4 \\
$\quad$ units) & 31 & 0.2 & 10.0 & 398 \\
Flow (cubic feet per second) & 31 & 0 & 1,160 & \\
\hline
\end{tabular}


Observed FTHg concentrations ranged from $0.48 \mathrm{ng} / \mathrm{L}$ on January 29, 2014, to $1.57 \mathrm{ng} / \mathrm{L}$ on September 23, 2015 (table 4). These concentrations were most highly correlated with laboratory-derived $\alpha_{254}(\mathrm{r}=0.70)$ and fDOM $(\mathrm{r}=0.59)$ (table 5). Observed FMeHg concentrations ranged from $<0.06 \mathrm{ng} / \mathrm{L}$ on April 25, 2016, to $0.31 \mathrm{ng} / \mathrm{L}$ on September 23, 2015. FMeHg was most highly correlated with PTHg $(r=0.58$ and turbidity $(r=0.57)$. Observed PTHg ranged from $0.10 \mathrm{ng} / \mathrm{L}$ on December 6, 2013, to $6.47 \mathrm{ng} / \mathrm{L}$ on September 23, 2015. Observed PMeHg ranged from $<0.003 \mathrm{ng} / \mathrm{L}$ on October 28,2014 , to $0.20 \mathrm{ng} / \mathrm{L}$ on September 23, 2015. Both PTHg and PMeHg were most strongly correlated with turbidity $(\mathrm{r}=0.96$ and $\mathrm{r}=0.88$, respectively).

\section{Channel Cross-Sectional Variability}

A total of 14 vertical sensor profiles (as described in the continuous monitoring section) were collected between September 11, 2013, and September 19, 2016. Raw fDOM values were used for comparison (that is, no corrections were applied for temperature, turbidity, or inner filter effect). Profile averages for fDOM measurements were within 10 percent (on average -4 percent) to the YSI EXO site monitor readings $(n=14)$, except for measurements on February 22 and July 18, 2016. Measurements at the continuous station on those dates were 17 and 24 percent lower, respectively, than the average for the channel profile data. The specific conductance data were also 17 and 19 percent lower on those dates, indicating that the variation between the continuous-recording station and the mean channel was not always consistent. The difference between the continuous station and mean crosssectional values for turbidity ranged from 0.2 to $-0.6 \mathrm{FNU}$, with a mean difference of -0.2 FNU (fig. 4).

The differences between values recorded at the continuous station and the average of measurements for the channel sensor profiles and the differences between the paired point and vertically integrated samples were not uniformly biased for constituents of interest. Despite these differences, it was concluded that the station data were representative of the mean channel under most conditions. It is recognized that this may

Table 3. Pearson correlation coefficients ( $r$ ) of observed dissolved organic carbon (DOC), decadic absorption coefficient at 254 nanometers $\left(\alpha_{254}\right)$, specific ultraviolet absorbance at 254 nanometers $\left(S U V A_{254}\right)$, specific conductance, fluorescence of chromophoric dissolved organic matter (fDOM), temperature, turbidity, and flow data collected at S-12D from September 2013 to December 2016.

\begin{tabular}{|c|c|c|c|c|c|c|c|}
\hline Data descriptor & $\begin{array}{l}\text { Dissolved organic } \\
\text { carbon (milli- } \\
\text { grams per liter) }\end{array}$ & $\begin{array}{c}\text { Decadic } \\
\text { absorption } \\
\text { coefficient at } \\
254 \text { nanome- } \\
\text { ters, } \alpha_{254}\end{array}$ & $\begin{array}{l}\text { SUVA }_{254} \\
\text { (liters per } \\
\text { milligram } \\
\text { carbon per } \\
\text { meter) }\end{array}$ & $\begin{array}{l}\text { Specific conduc- } \\
\text { tance (micro- } \\
\text { siemens per } \\
\text { centimeter at } 25 \\
\text { degrees Celsius) }\end{array}$ & $\begin{array}{l}\text { fDOM (qui- } \\
\text { nine sulfate } \\
\text { equivalent) }\end{array}$ & $\begin{array}{c}\text { Temperature } \\
\text { (degrees } \\
\text { Celsius) }\end{array}$ & $\begin{array}{r}\text { Turbidity } \\
\text { (formazin } \\
\text { nephelo- } \\
\text { metric } \\
\text { units) }\end{array}$ \\
\hline \multicolumn{8}{|l|}{$\begin{array}{l}\text { Dissolved organic } \\
\text { carbon (milli- } \\
\text { grams per liter) }\end{array}$} \\
\hline $\begin{array}{l}\text { Decadic absorption } \\
\text { coefficient at } 254 \\
\text { nanometers, } \alpha_{254}\end{array}$ & 0.871 & & & & & & \\
\hline $\begin{array}{l}\mathrm{SUVA}_{254} \text { (liters per } \\
\text { milligram carbon } \\
\text { per meter) }\end{array}$ & 0.279 & 0.687 & & & & & \\
\hline $\begin{array}{l}\text { Specific conductance } \\
\text { (microsiemens per } \\
\text { centimeter at } 25 \\
\text { degrees Celsius) }\end{array}$ & 0.834 & 0.671 & 0.171 & & & & \\
\hline $\begin{array}{l}\text { fDOM (quinine sul- } \\
\text { fate equivalent) }\end{array}$ & 0.809 & 0.954 & 0.687 & 0.649 & & & \\
\hline $\begin{array}{l}\text { Temperature (de- } \\
\text { grees Celsius) }\end{array}$ & 0.036 & 0.099 & 0.105 & -0.120 & 0.095 & & \\
\hline $\begin{array}{l}\text { Turbidity (formazin } \\
\text { nephelometric } \\
\text { units) }\end{array}$ & 0.151 & 0.096 & -0.025 & 0.386 & 0.113 & 0.241 & \\
\hline $\begin{array}{l}\text { Flow (cubic feet per } \\
\text { second) }\end{array}$ & 0.086 & 0.411 & 0.565 & -0.107 & 0.335 & -0.092 & -0.395 \\
\hline
\end{tabular}


not always hold true, particularly for turbidity, which is the sole predictive measurement used to model PTHg and PMeHg concentrations; this is a limitation of the study. The location of the point sensor for continuous in situ measurements was not directly in the path of highest flow velocity. Therefore, because the concentration of suspended particulate matter is expected to be positively correlated with flow velocity, values of suspended matter measured at the high-velocity point are also expected to be higher than those recorded at the point sensor. The calculated PTHg and PMeHg are expected to be representative of the location of the point sensor but may modestly underpredict the concentrations at the location of highest flow velocity.

During the period January 2013 through February 2015, between 12 and 15 pairs of vertically integrated samples were collected at the point of highest velocity at structure S-12D, and point samples were collected near the site monitor location for analyses of FTHg, FMeHg, PTHg, and PMeHg (fig. 5). The difference in value for FTHg between the paired point and vertically integrated samples ranged from -9 to +7 percent, with an average of -2 percent $(n=14)$. The difference in value for FMeHg between the paired point and vertically integrated samples ranged from -22 percent $(-0.02 \mathrm{ng} / \mathrm{L})$ to +26 percent $(0.05 \mathrm{ng} / \mathrm{L})$, with an average of zero percent $(n=13)$. The difference in value for PTHg between the paired point and vertically integrated samples ranged from -50 to +8 percent, with an average of -10 percent $(n=15)$. The difference in value for PMeHg between the paired point and vertically integrated samples ranged from -55 to +27 percent, with an average of -7 percent $(n=14)$. The scatter plots in figure 5 show good agreement between the concentration of point samples and the concentration of vertically integrated samples for FTHg and FMeHg. For PTHg and PMeHg; however, the concentrations of point samples compared to the concentrations of vertically integrated samples showed more variability. The concentrations of point samples for PTHg and PMeHg were lower than concentrations of the vertically integrated samples at the location of highest flow, particularly when concentrations were higher, although no clear trends were observed with differences in flow rate.

Table 4. Number of observations, minimum, maximum, and mean concentrations of observed filter-passing total mercury (FTHg) and methylmercury (FMeHg), particulate total mercury (PTHg) and methylmercury (PMeHg), dissolved organic carbon (DOC), decadic absorption coefficient at 254 nanometers $\left(\alpha_{254}\right)$, specific ultraviolet absorbance at 254 nanometers $\left(S_{U V A} A_{254}\right)$, specific conductance, fluorescence of chromophoric dissolved organic matter (fDOM), temperature, turbidity, and flow data collected at S-12D from September 2013 to December 2016.

\begin{tabular}{|c|c|c|c|c|}
\hline Data descriptor & Observations & Minimum & Maximum & Mean \\
\hline Filtered total mercury (nanograms per liter) & 26 & 0.48 & 1.57 & 0.90 \\
\hline Filtered methylmercury (nanograms per liter) & 26 & $<0.06$ & 0.31 & 0.15 \\
\hline Particulate total mercury, (nanograms per liter) & 26 & 0.10 & 6.47 & 0.76 \\
\hline $\begin{array}{l}\text { Particulate methylmercury, (nanograms per } \\
\text { liter) }\end{array}$ & 26 & $<0.006$ & 0.20 & 0.04 \\
\hline $\begin{array}{l}\text { Dissolved organic carbon (milligrams per } \\
\text { liter) }{ }^{1}\end{array}$ & 31 & 13.4 & 25.8 & 19.1 \\
\hline $\begin{array}{l}\text { Decadic absorption coefficient at } 254 \text { nanome- } \\
\text { ters, } \alpha_{254}{ }^{1}\end{array}$ & 30 & 0.34 & 0.78 & 0.55 \\
\hline $\begin{array}{l}\mathrm{SUVA}_{254} \text {, (liters per milligram carbon per } \\
\text { meter) }{ }^{1}\end{array}$ & 30 & 2.2 & 3.5 & 2.9 \\
\hline $\begin{array}{l}\text { Specific conductance (microsiemens per centi- } \\
\text { meter at } 25 \text { degrees Celsius) }\end{array}$ & 27 & 369 & 796 & 554 \\
\hline fDOM (quinine sulfate equivalents) & 27 & 118 & 538 & 294 \\
\hline Temperature (degrees Celsius) & 27 & 18.2 & 30.4 & 25.7 \\
\hline Turbidity (formazin nephelometric units) & 27 & 0.2 & 16.0 & 2.1 \\
\hline Discharge (cubic feet per second) & 27 & 0 & 1,160 & 359 \\
\hline
\end{tabular}

1Dissolved organic carbon, decadic absorption at 254 nanometers and specific ultraviolet absorbance at 254 nanometers values were all collected on the same date as mercury constituents; however, the times varied by 2 hours or less. The field data (fDOM, temperature, turbidity, specific conductance, and discharge) in the table all correlate with the time the mercury $(\mathrm{Hg})$ samples were collected. 


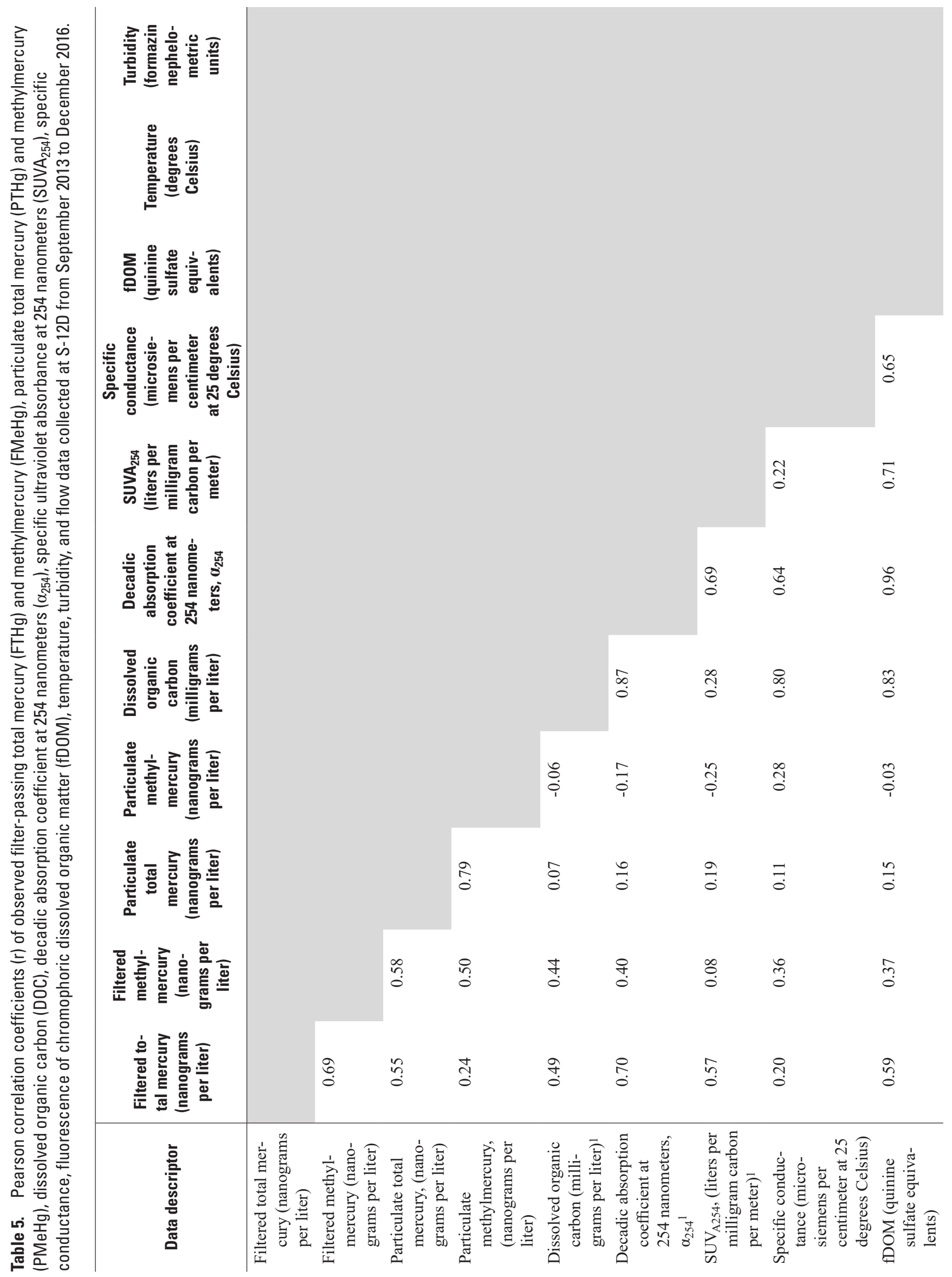




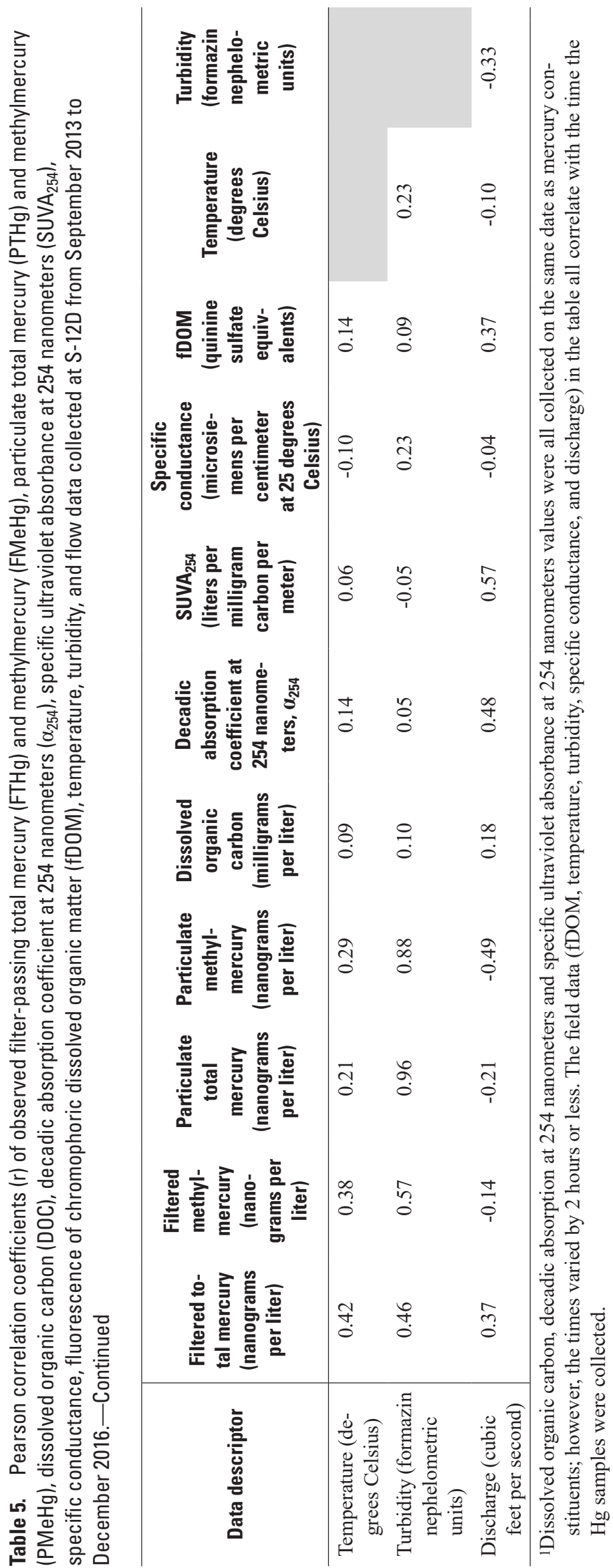



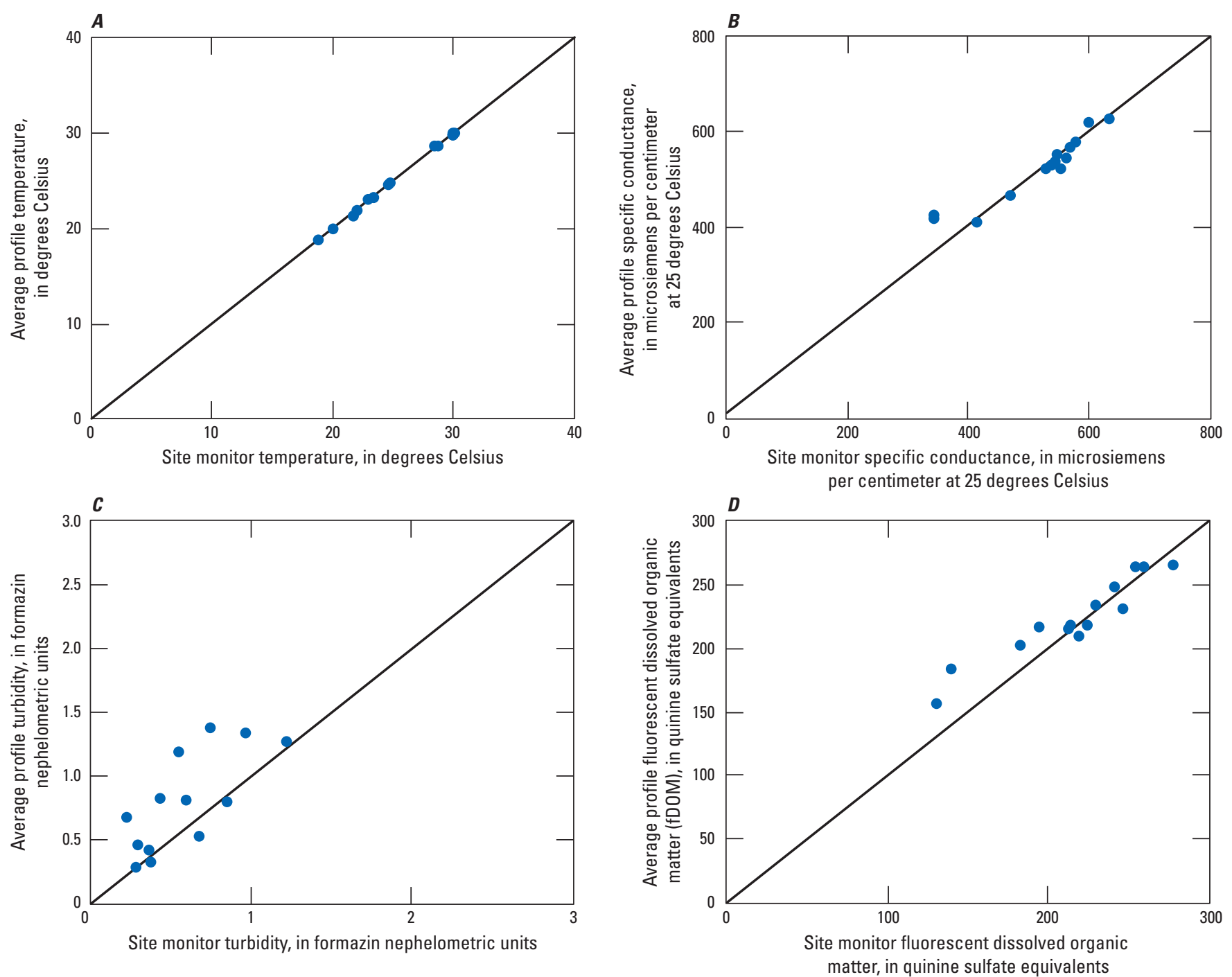

Figure 4. Comparisons between mean cross-sectional profile data and site monitor data for, $A$, temperature, $B$, specific conductance, $C$, turbidity, and $D$, fluorescence of chromophoric dissolved organic matter (fDOM). The 1:1 line is shown in black. 

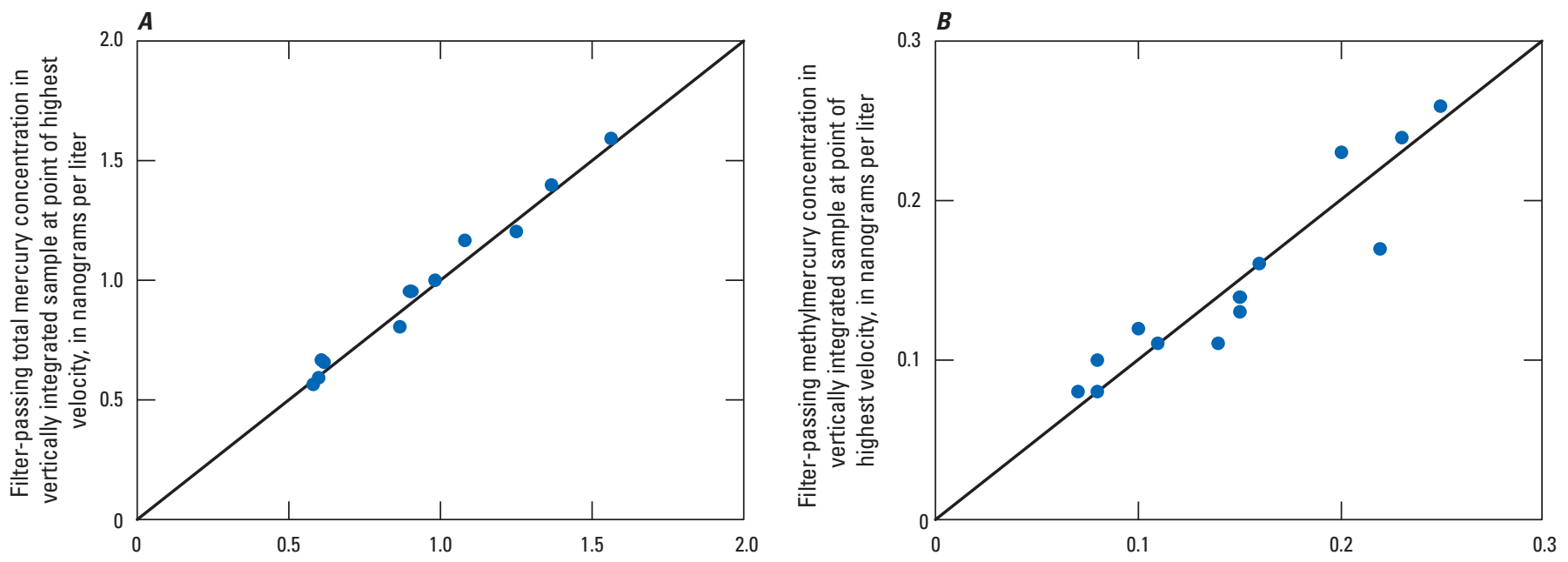

Filter-passing total mercury concentration in
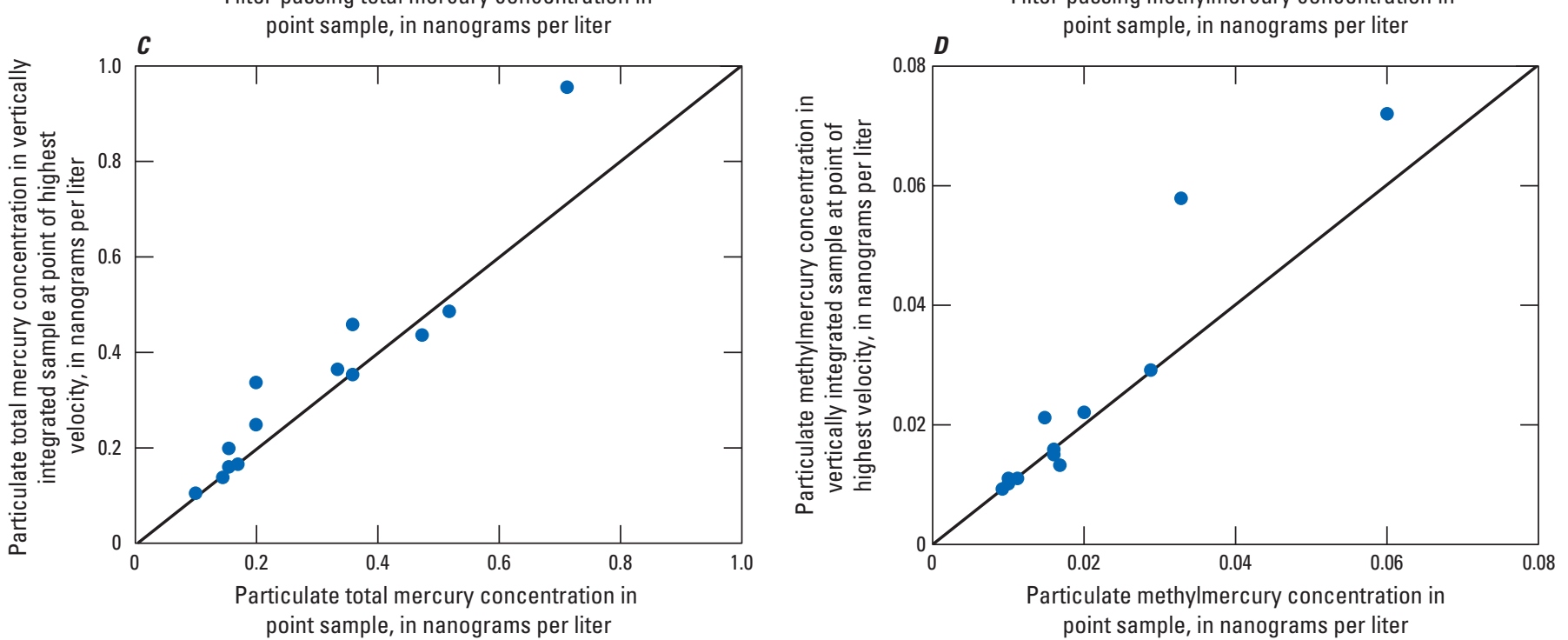

Figure 5. Comparisons between point sample and vertically integrated samples at point of highest flow for $A$, Filter-passing total mercury (FTHg), $B$, filter-passing methylmercury $(\mathrm{FMeHg}), C$, particulate total mercury (PTHg), and $D$, particulate methylmercury (PMeHg). The 1:1 line is shown in black. 


\section{Empirical Models}

Empirical models used to calculate $\mathrm{Hg}$ and DOC concentrations are described in this section of the report. Additional information on the models can be found in appendixes $1-5$.

\section{Dissolved Organic Carbon Model}

The best predictors of DOC concentration were fDOM and $\mathrm{SC}$, as represented in the following equation:

$$
D O C=(0.016 \times S C)+(0.0143 \times f D O M)+6.26,
$$

where

$$
\begin{aligned}
& D O C \text { is dissolved organic carbon concentration, in } \\
& \text { milligrams per liter; } \\
& S C \text { is specific conductance, in microsiemens per } \\
& \text { centimeter at } 25 \text { degrees Celsius; and } \\
& \text { fDOM is fluorescence of chromophoric dissolved } \\
& \text { organic matter, in quinine sulfate } \\
& \text { equivalents. }
\end{aligned}
$$

The values of fDOM were corrected for temperature, turbidity, and inner filter effects. The regression model is based on 31 concurrent measurements of DOC, fDOM, and specific conductance (SC) on samples collected from September 11, 2013, to December 19, 2016. The coefficient of determination $\left(\mathrm{R}^{2}\right)$ for the model is 0.819 , the standard error is (RMSE) 1.32 and the average model standard percentage error (MSPE) is 6.94.

\section{Filter-Passing Total Mercury Model}

The best predictors of FTHg were temperature and $\mathrm{fDOM}$, as represented in the following equation:

$$
\begin{gathered}
\text { FTHg }=\left(1.68 \times 10^{-3} \times f D O M\right)+ \\
\left(2.64 \times 10^{-2} \times T\right)-0.293
\end{gathered},
$$

where

$$
\begin{gathered}
\text { FTHg is filter-passing total mercury concentration, } \\
\text { in nanograms per liter; and } \\
T \quad \text { is temperature, in degrees Celsius. }
\end{gathered}
$$

The regression model is based on 25 concurrent measurements of FTHg, temperature, and fDOM collected from September 11, 2013, to December 19, 2016. The $\mathrm{R}^{2}$ for the model is 0.499 , the RMSE is 0.227 , and the MSPE is 25.9.

\section{Filter-Passing Methylmercury Model}

The best predictors of $\mathrm{FMeHg}$ were temperature and $\mathrm{fDOM}$, as represented in the following equation:

$$
\begin{gathered}
F M e H g=\left(2.1 \times 10^{-4} \times f D O M\right) \\
\quad+\left(5.27 \times 10^{-3} \times T\right)-0.0534
\end{gathered}
$$

where

$\mathrm{FMeHg}$ is filter-passing methylmercury concentration, in nanograms per liter.

The regression model is based upon 25 concurrent measurements of $\mathrm{FMeHg}$, temperature, and fDOM collected from September 11, 2013, to December 19, 2016. The coefficient of determination is low for this model $\left(\mathrm{R}^{2}=0.244\right)$, indicating that additional factors influence FMeHg concentration. Implications of model accuracy will be discussed later in the report. The RMSE for the model is 0.0593 and the MSPE is 41.5

\section{Particulate Total Mercury Model}

The best predictor of PTHg was natural log transformed turbidity, as represented in the following equation:

$$
\ln (P T H g)=(0.701 \times \ln [\text { Turbidity }])-0.906,
$$

where

PTHg is particulate total mercury concentration, in nanograms per liter; and

Turbidity is turbidity (YSI EXO model), in formazin nephelometric units.

The regression model is based on 26 concurrent measurements of PTHg and turbidity, collected from September 11, 2013, to October 26, 2016. The $\mathrm{R}^{2}$ for the model is 0.703 , the RMSE is 0.522 , and the MSPE is 54.6. A bias correction factor of 1.15 was applied to correct for retransformation.

\section{Particulate Methylmercury Model}

The best predictor of PMeHg was natural log transformed turbidity, as represented in the following equation:

$$
\ln (P M e H g)=(0.752 \times \ln [\text { Turbidity }])-3.82,
$$

where

$\mathrm{PMeHg}$ is particulate methylmercury concentration, in nanograms per liter.

The regression model is based on 26 concurrent measurements of PMeHg and turbidity, collected from September 11, 2013, to October 26, 2016. Of the samples collected, concentrations of PMeHg in 8 percent ( 2 of the 26) were below the detection limit. Half of the detection limit was used for the censored data during the model development. The $\mathrm{R}^{2}$ for the model is 0.603, the RMSE is 0.7, and the MSPE is 75.9. A bias correction factor of 1.23 was applied to correct for retransformation. 


\section{Dissolved Organic Carbon Concentrations and Loads}

Calculated concentrations of DOC ranged from on February 14, 2014, to $27.9 \mathrm{mg} / \mathrm{L}$ on July 30, 2014 (fig. 6). The mean calculated DOC concentration for the study period was $18.8 \mathrm{mg} / \mathrm{L}$, and the monthly average of DOC ranged from $14.3 \mathrm{mg} / \mathrm{L}$ in March 2017 to $23.3 \mathrm{mg} / \mathrm{L}$ in August 2014. The greatest range in DOC concentrations occurred at flows between 200 and $400 \mathrm{ft} 3 / \mathrm{s}$. At flows higher than $400 \mathrm{ft}^{3} / \mathrm{s}$, the range in DOC concentrations decreased, as did the median and average concentrations.

Annual loads of DOC were 6,230 tons of organic carbon in calendar year 2014, 3,950 tons in calendar year 2015, and 10,900 tons in calendar year 2016 (fig. 7). Calculated daily loads of DOC ranged from zero to 62 tons on February 7, 2016, and monthly loads were zero during periods of no flow (May 2014, April to August 2015, and January to March 2017). Monthly mean flow explained 97 percent of the variance in monthly DOC loads. DOC loads increased linearly with an increase in flow, and the highest monthly load (1,630 tons) occurred during February 2016. The high monthly load in February 2016 can be attributed to January 2016 being the wettest January in 100 years for most of Florida, with cumulative rainfall of 9.5 inches over Water Conservation Area 3A to the north of structure S-12D (Abtew and Ciuca, 2017).

\section{Mercury Concentrations and Loads}

Calculated concentrations of FTHg ranged from $0.35 \mathrm{ng} / \mathrm{L}$ on January 27, 2014, to $1.55 \mathrm{ng} / \mathrm{L}$ on August 1, 2014 (fig. $8 A$ ). The mean calculated FTHg concentration was $0.85 \mathrm{ng} / \mathrm{L}$ over the duration of the study, and the monthly mean concentration of FTHg ranged from $0.51 \mathrm{ng} / \mathrm{L}$ in March 2017 to $1.29 \mathrm{ng} / \mathrm{L}$ in August 2014. Calculated concentrations of FMeHg ranged from $0.06 \mathrm{ng} / \mathrm{L}$ on January 27, 2014, to $0.24 \mathrm{ng} / \mathrm{L}$ on August 1, 2014 (fig. 8B). The mean calculated FMeHg concentration was $0.14 \mathrm{ng} / \mathrm{L}$ over the duration of the study. The differences between the observed and calculated $\mathrm{FMeHg}$ values appear to increase beginning in 2015, indicating additional influences on $\mathrm{MeHg}$ that are not accounted for in the model. The calculated monthly mean concentration of FMeHg ranged from $0.09 \mathrm{ng} / \mathrm{L}$ in January 2015 and March 2017 to 0.20 ng/L in August 2014. Calculated concentrations of FTHg were greater than $1.4 \mathrm{ng} / \mathrm{L}$ only for flows between 190 and $550 \mathrm{ft} 3 / \mathrm{s}$, and calculated concentrations of FMeHg were greater than $0.2 \mathrm{ng} / \mathrm{L}$ only for flows between 190 and $650 \mathrm{ft} 3 / \mathrm{s}$. Annually, concentrations of FTHg and FMeHg were highest during August and September.

Calculated concentrations of $\mathrm{PTHg}$ ranged from $0.09 \mathrm{ng} / \mathrm{L}$ on September 10, 2013, February 11, and April 25, 2016, to $4.19 \mathrm{ng} / \mathrm{L}$ on December 10 and 12, 2014, and February 24, 2015 (fig. 9A). The mean calculated PTHg concentration was $0.58 \mathrm{ng} / \mathrm{L}$ over the duration of the study. The monthly average of PTHg ranged from $0.28 \mathrm{ng} / \mathrm{L}$ in November 2013 to $1.31 \mathrm{ng} / \mathrm{L}$ in June 2014. Calculated concentrations of $\mathrm{PMeHg}$ ranged from $<0.01 \mathrm{ng} / \mathrm{L}$ on September 10, 2013, February 11, and April 25, 2016, to $0.29 \mathrm{ng} / \mathrm{L}$ on December 10 and December 12, 2014, and February 24, 2015 (fig. 9B). The mean calculated PMeHg concentration was $0.03 \mathrm{ng} / \mathrm{L}$ over the duration of the study. The monthly mean concentration of $\mathrm{PMeHg}$ ranged from $0.01 \mathrm{ng} / \mathrm{L}$ in November 2013 and March 2016 to $0.08 \mathrm{ng} / \mathrm{L}$ in June 2014. The maximum concentrations of PTHg and PMeHg varied throughout the year. The annual monthly mean concentrations of PTHg and PMeHG were highest in June 2014, August 2015, and December 2016. The monthly concentrations of both PTHg and PMeHg were lowest in months with low monthly mean flow.

Calculated daily loads of FTHg and PTHg ranged from zero to $4.2 \mathrm{~g}$ on February 21, 2016. Based on daily load calculations, PTHg accounted for 16-67 percent of the summation of filter-passing and particulate $\mathrm{THg}$. These estimates over the entire study period are in good agreement with discrete observations where the observed PTHg accounted for 11-87 percent of the summation of filter-passing and particulate $\mathrm{THg}$. Monthly loads of FTHg and PTHg were zero in May 2014, from April to August 2015, and from January to March 2017 because there was no flow. The maximum monthly load of FTHg and PTHg was $85.6 \mathrm{~g}$ in September 2016. Annual loads of FTHg ranged from $154 \mathrm{~g}$ in 2015 to $455 \mathrm{~g}$ in 2016, and annual loads of PTHg ranged from $96 \mathrm{~g}$ in 2015 to $204 \mathrm{~g}$ in 2016 (fig. 10). As expected, the loads of FTHg and PTHg are often minimal during periods of low flow. Monthly mean flow explained 90 percent of the variance in monthly mean FTHg loads and 66 percent of the variance in monthly mean PTHg loads.

Calculated daily loads of $\mathrm{FMeHg}$ and $\mathrm{PMeHg}$ ranged from zero to $0.4 \mathrm{~g}$ on February 21, 2016. Based on daily load calculations, $\mathrm{PMeHg}$ accounted for 6-50 percent of the summation of filter-passing and particulate $\mathrm{MeHg}$, which agrees well with discrete observations. Observed $\mathrm{PMeHg}$ ranged from 2 to 55 percent of the summation of filter-passing and particulate $\mathrm{MeHg}$. Monthly loads of FMeHg and $\mathrm{PMeHg}$ were zero in May 2014, from April to August 2015, and from January to March 2017. The maximum monthly load of FMeHg and PMeHg was $11.2 \mathrm{~g}$ in September 2016. Annual loads of FMeHg ranged from $25.0 \mathrm{~g}$ in 2015 to $75.6 \mathrm{~g}$ in 2016, and annual loads of PTHg ranged from $5.7 \mathrm{~g}$ in 2015 to $11.7 \mathrm{~g}$ in 2016 (fig. 11). As expected, the loads were often zero or very low during periods of low flow. Monthly mean flow explained 91 percent of the variance in monthly mean FMeHg loads and 62 percent of the variance in monthly mean $\mathrm{PMeHg}$ loads. The summation of FMeHg and PMeHg accounted for 8-15 percent (averaged 13 percent) of the daily mean of total $\mathrm{Hg}$ (summation of FTHg and PTHg).

When gates are initially opened or following changes in gate operations at S-12D, PTHg and $\mathrm{PMeHg}$ were a greater percentage of the $\mathrm{Hg}$ load. We attribute this observation to 


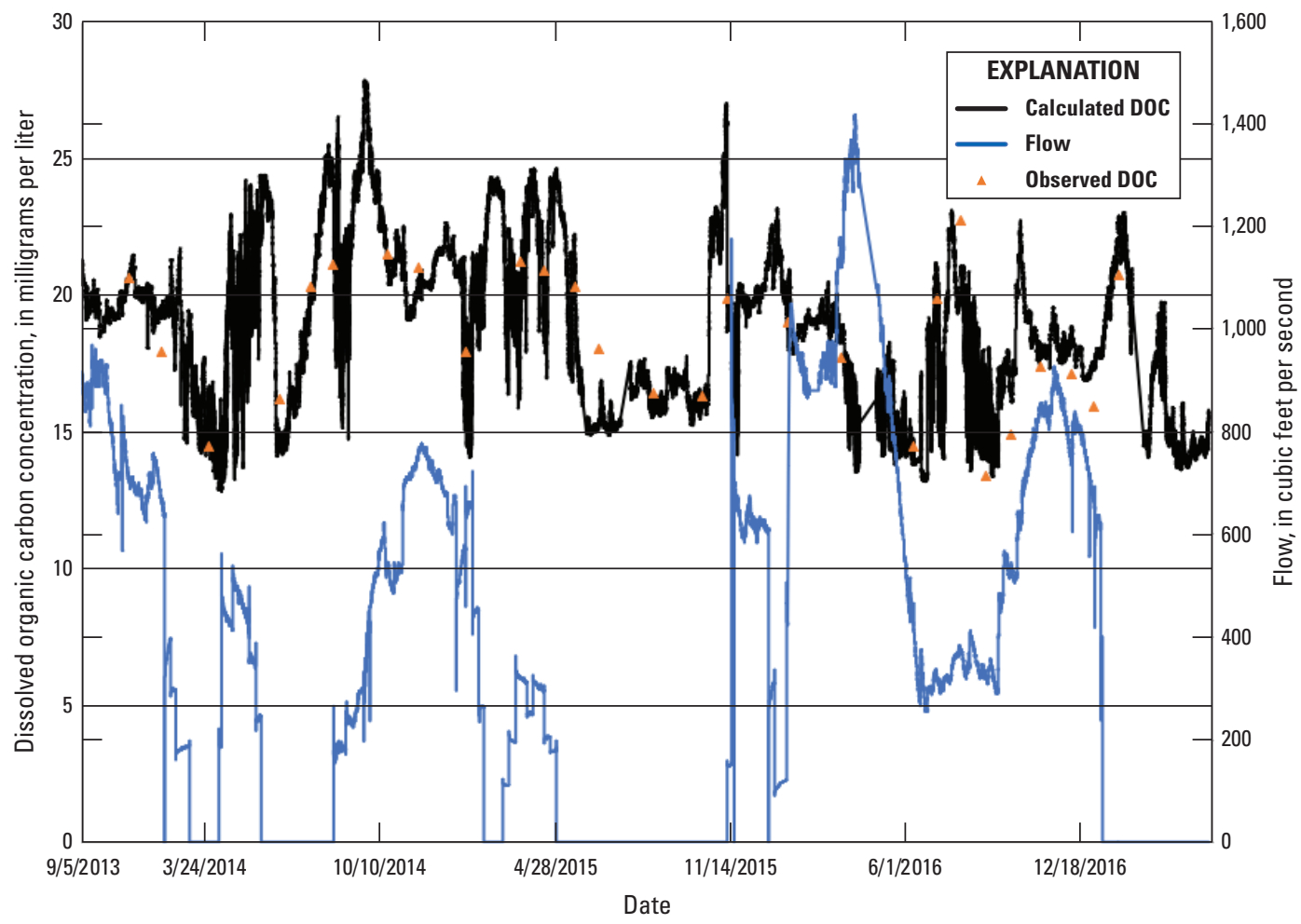

Figure 6. Calculated and observed concentrations of dissolved organic carbon (DOC) and flow.

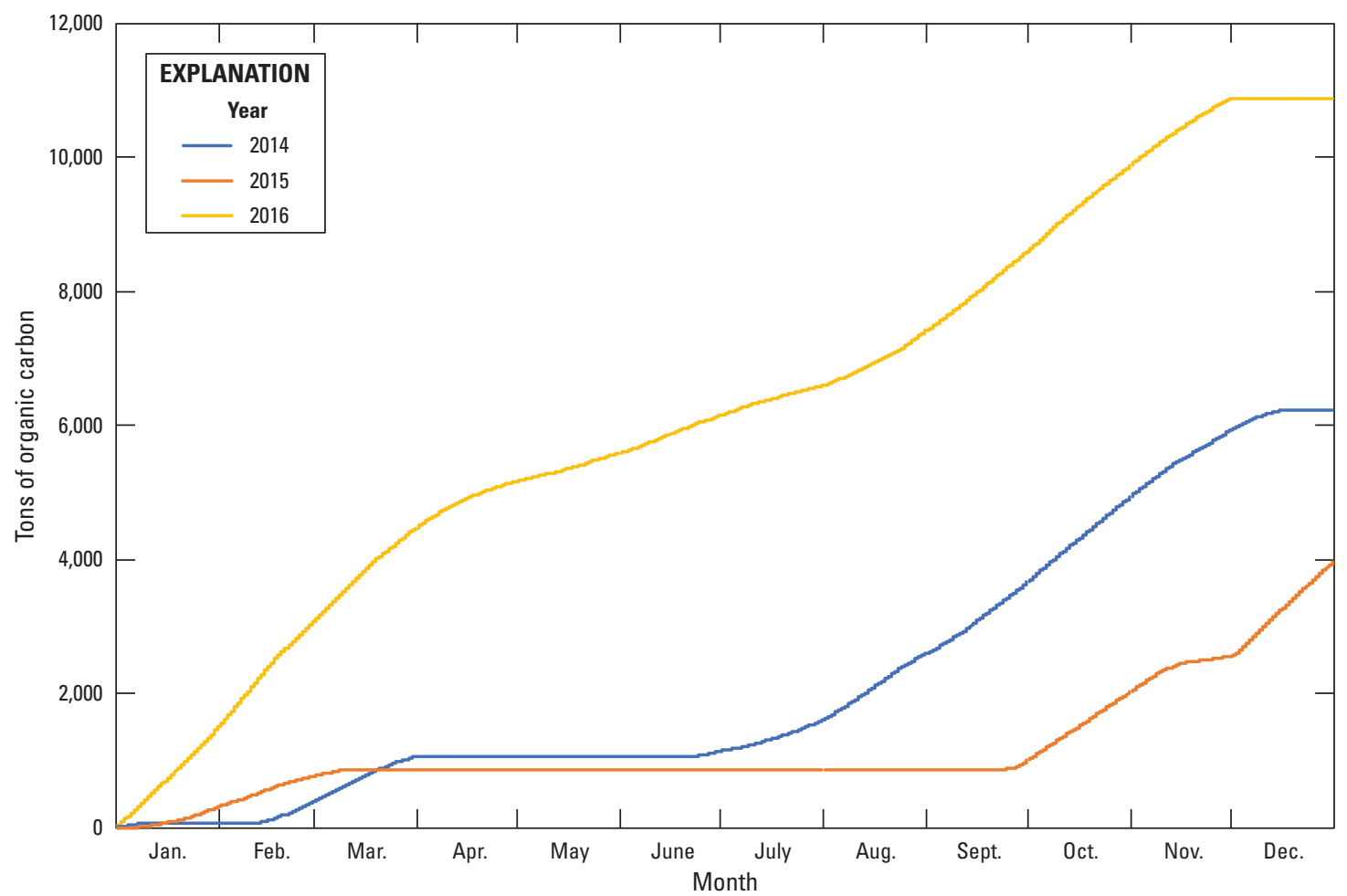

Figure 7. Cumulative loads of dissolved organic carbon for calendar years 2014-16. 

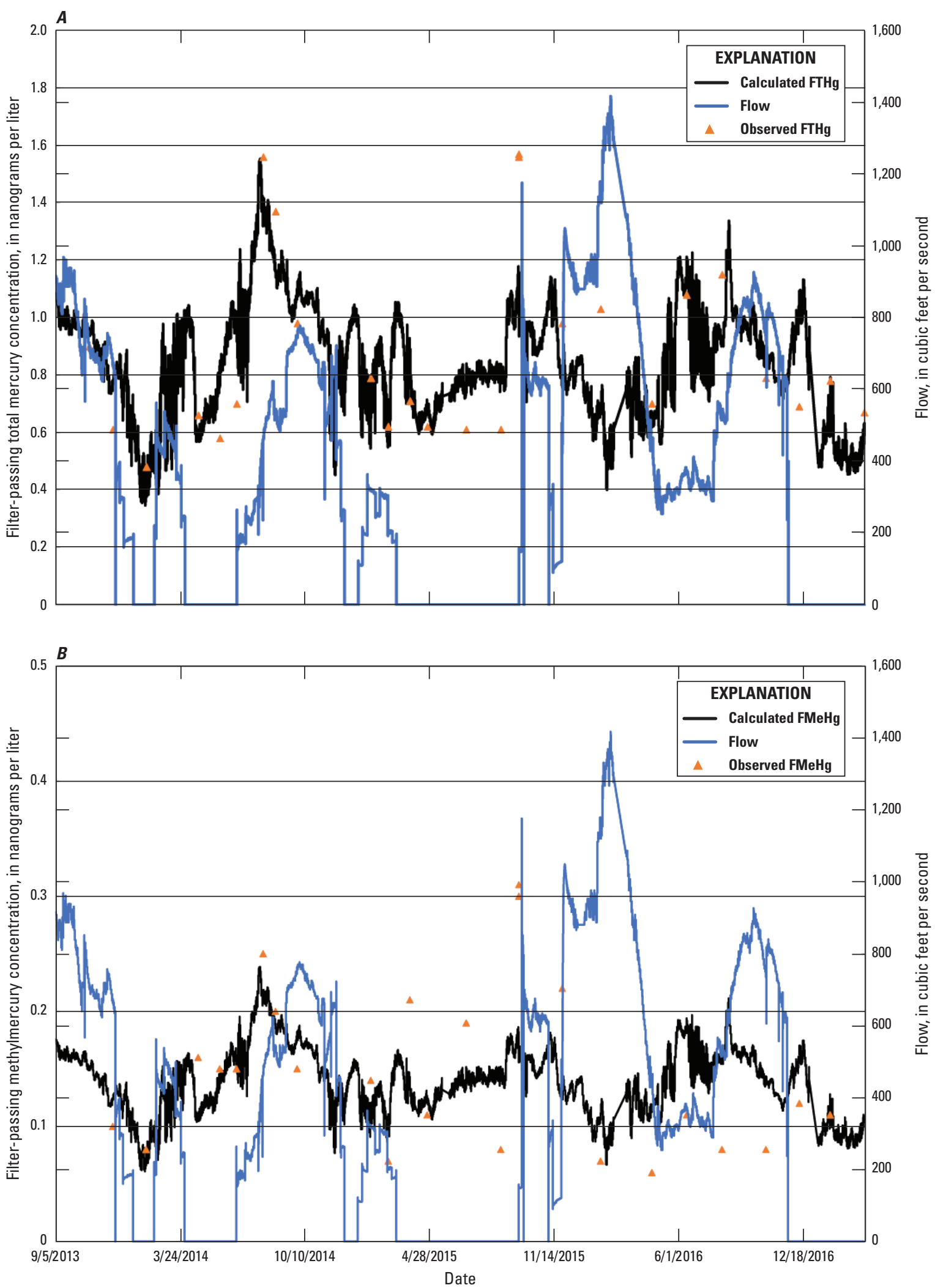

Figure 8. $\quad A$, Calculated and observed filter-passing total mercury (FTHg) concentrations and flow. $B$, Calculated and observed filter-passing methylmercury (FMeHg) concentrations and flow. 

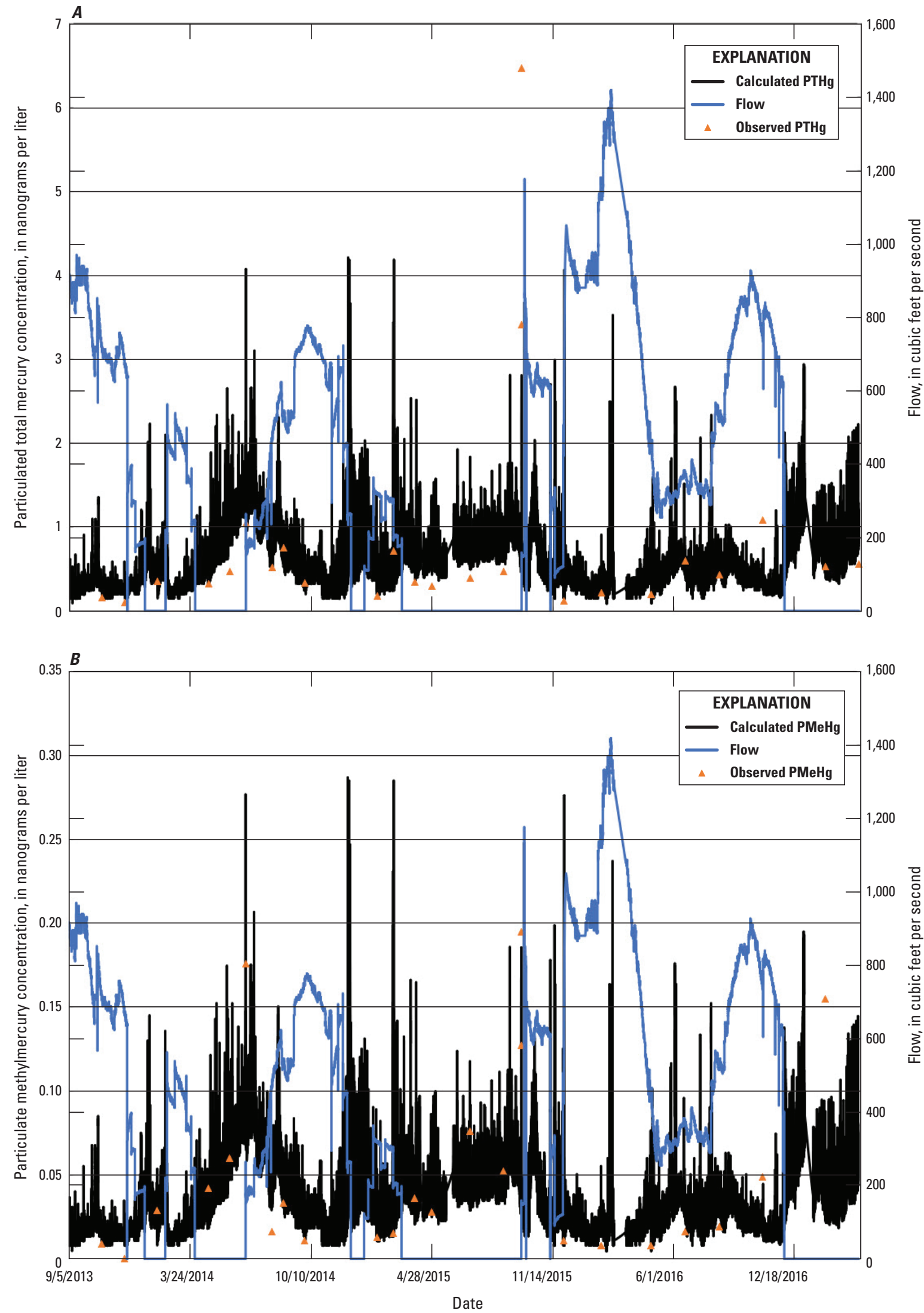

Figure 9. A, Calculated and observed concentrations of particulate total mercury (PTHg) and flow. B, Calculated and observed particulate methylmercury (PMeHg) concentrations and flow. 


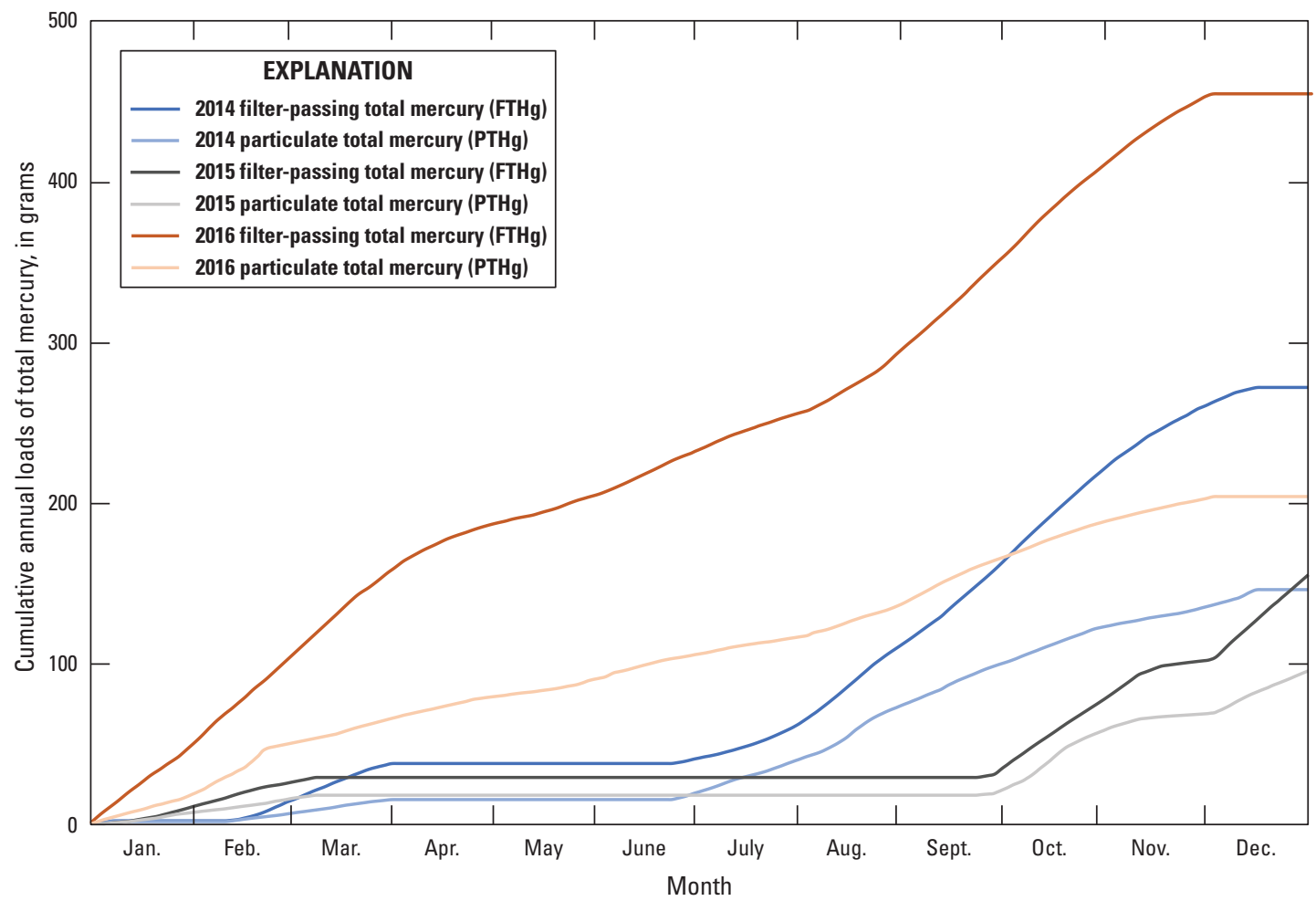

Figure 10. Cumulative loads of total mercury $(\mathrm{Hg})$ for 2014-16 calendar years.

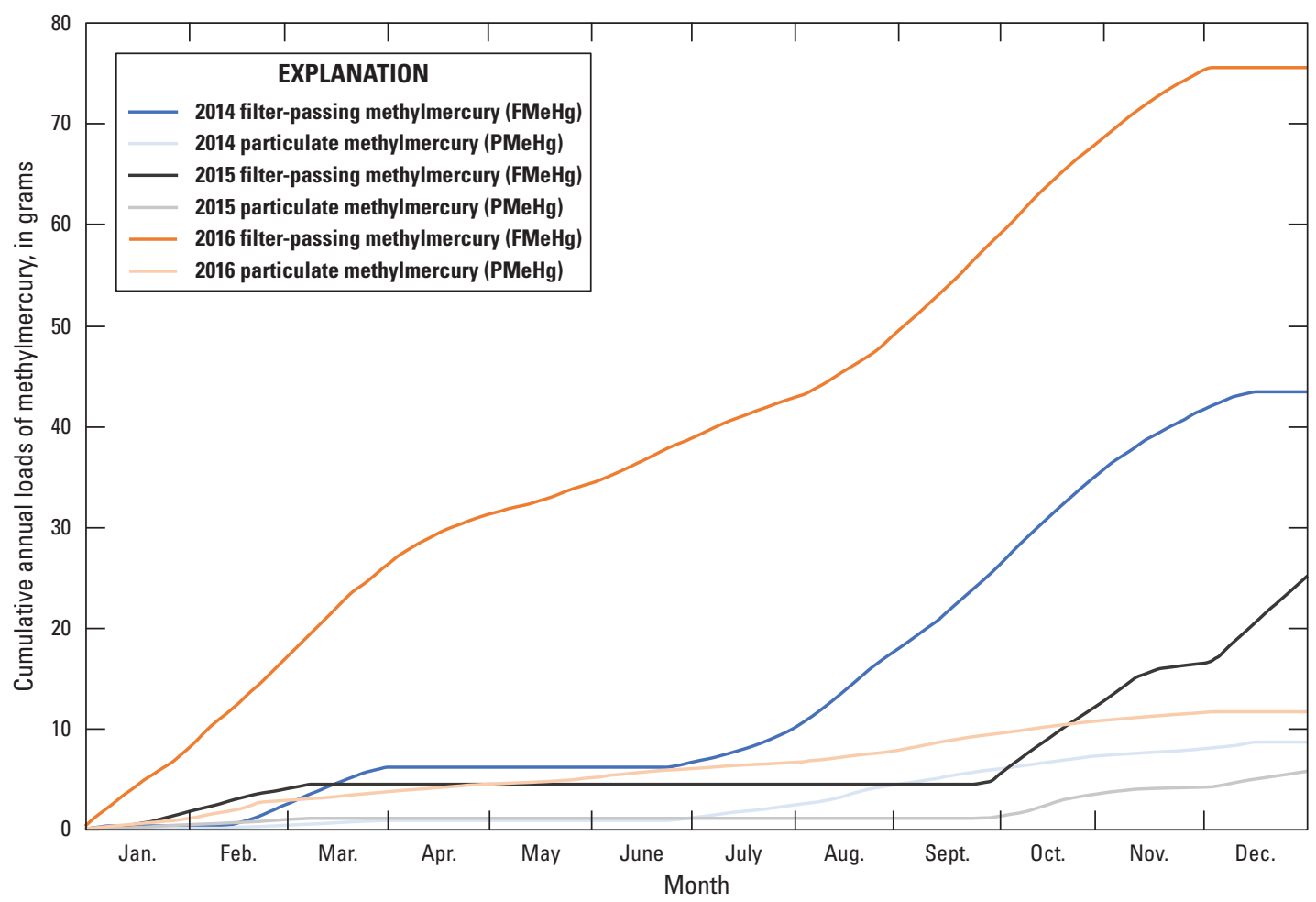

Figure 11. Cumulative loads of methylmercury (MeHg) for calendar years 2014-16. 
the resuspension of material deposited behind the gates during no-flow periods and during brief periods of higher flows, resulting in the transport of suspended materials downstream to Everglades National Park. This condition was demonstrated on June 24, 2014, and September 23, 2015, when multiple samples were collected under varying gate openings. Calculations of daily load indicated that 6 percent of PTHg was PMeHg.

Annual loads of total $\mathrm{Hg}$ (sum of filter-passing and particulate) were 419, 254, and $658 \mathrm{~g}$ in calendar years 2014, 2015, and 2016, respectively. FTHg was the predominant contributor to the total $\mathrm{Hg}$ load (65-69 percent annually). Annually, only 6 percent of the PTHg load and 16 percent of the FTHg load was in the form of $\mathrm{PMeHg}$ and $\mathrm{FMeHg}$, respectively.

\section{Comparison of Observed Loads to Calculated Loads}

One-minute loads were calculated using observed concentrations and calculated concentrations and compared (fig. 12). Linear regression comparison between calculated and observed 1-minute DOC loads, indicated that 99.5 percent of the variance has been accounted for, suggesting that the loads calculated using the surrogate approach are representative of the observed values. It is not surprising that the highest $\mathrm{R}^{2}$ for calculated versus observed loads was for the DOC comparison. The model to calculate DOC concentrations had the highest $\mathrm{R}^{2}$ and lowest relative concentration model bias of all calculated constituents (table 6).
Linear regression comparison indicated that the calculated loads accounted for 91.5 percent of the variation between calculated and observed FTHg 1-minute loads and 79.7 percent of the variation between calculated and observed FMeHg 1-minute loads. The relative load model bias was highest for the 1-minute load FMeHg model; however, the FMeHg loads were still predicted with a reasonable degree of accuracy. This analysis indicates that the load calculations calculated using surrogate models for DOC, FTHg, and FMeHg are a good representation of observed conditions.

Linear regression comparison indicated that the calculated loads accounted for 61.7 percent of the variation between calculated and observed PTHg and 52.7 percent of the variation between calculated and observed PMeHg. While the PTHg and PMeHg concentration models had relatively high $\mathrm{R}^{2}$ values, they also had higher RMSE and relative concentration model bias values than the other models. Graphical comparison shows that calculated concentrations are a good representation of the observed loads most of the time; however, on several sampling dates, the difference between the observed and calculated values were substantial and are potentially undercalculating the load of PTHg.

This analysis shows that the need for flow data is essential for calculating accurate load data. Notably, the error associated with calculated and observed flow data was not assessed as part of this study. Measurements are typically made every 2 weeks in order to maintain the maximum possible accuracy in flow record at this location; however, uneven distribution of flow, minimal elevation gradient, a lack of defined control, and variations in sedimentation and vegetation all decrease the accuracy of the calculated discharge at this location.

Table 6. Coefficient of determination $\left(R^{2}\right)$, model standard error (RMSE), and relative model bias for concentration models and calculated versus observed loads of dissolved organic carbon (DOC), filter-passing total mercury (FTHg) and methylmercury (FMeHg), particulate total mercury (PTHg) and methylmercury (PMeHg).

[Concentrations of DOC were calculated in milligrams per liter, and FTHG, FMeHG, PTHg, and PMeHg concentrations were calculated in nanograms per liter. Loads were calculated in tons per minute for DOC and grams per minute for FTHG, FMeHG, PTHg, and PMeHg]

\begin{tabular}{|c|c|c|c|c|c|c|}
\hline Data descriptor & $\begin{array}{c}\text { Concentration } \\
\text { model coefficient } \\
\text { of determination } \\
\left(\mathbf{R}^{2}\right)\end{array}$ & $\begin{array}{l}\text { Concentration } \\
\text { model standard } \\
\text { error (RMSE) }\end{array}$ & $\begin{array}{l}\text { Relative concentration } \\
\text { model bias }\end{array}$ & $\begin{array}{c}\text { Calculated verses } \\
\text { observed load coef- } \\
\text { ficient of determina- } \\
\text { tion }\left(\mathrm{R}^{2}\right)\end{array}$ & $\begin{array}{l}\text { Load model } \\
\text { standard er- } \\
\text { ror (RMSE) }\end{array}$ & $\begin{array}{c}\text { Relative load } \\
\text { model bias }\end{array}$ \\
\hline DOC & 0.819 & 1.32 & -0.012 & 0.995 & 0.0008 & -0.003 \\
\hline FTHg & 0.499 & 0.23 & 0.024 & 0.915 & 0.0002 & 0.039 \\
\hline $\mathrm{FMeHg}$ & 0.244 & 0.10 & 0.029 & 0.797 & 0.0000 & 0.227 \\
\hline $\mathrm{PMeHg}$ & 0.603 & 0.70 & 0.177 & 0.527 & 0.0000 & -0.003 \\
\hline
\end{tabular}




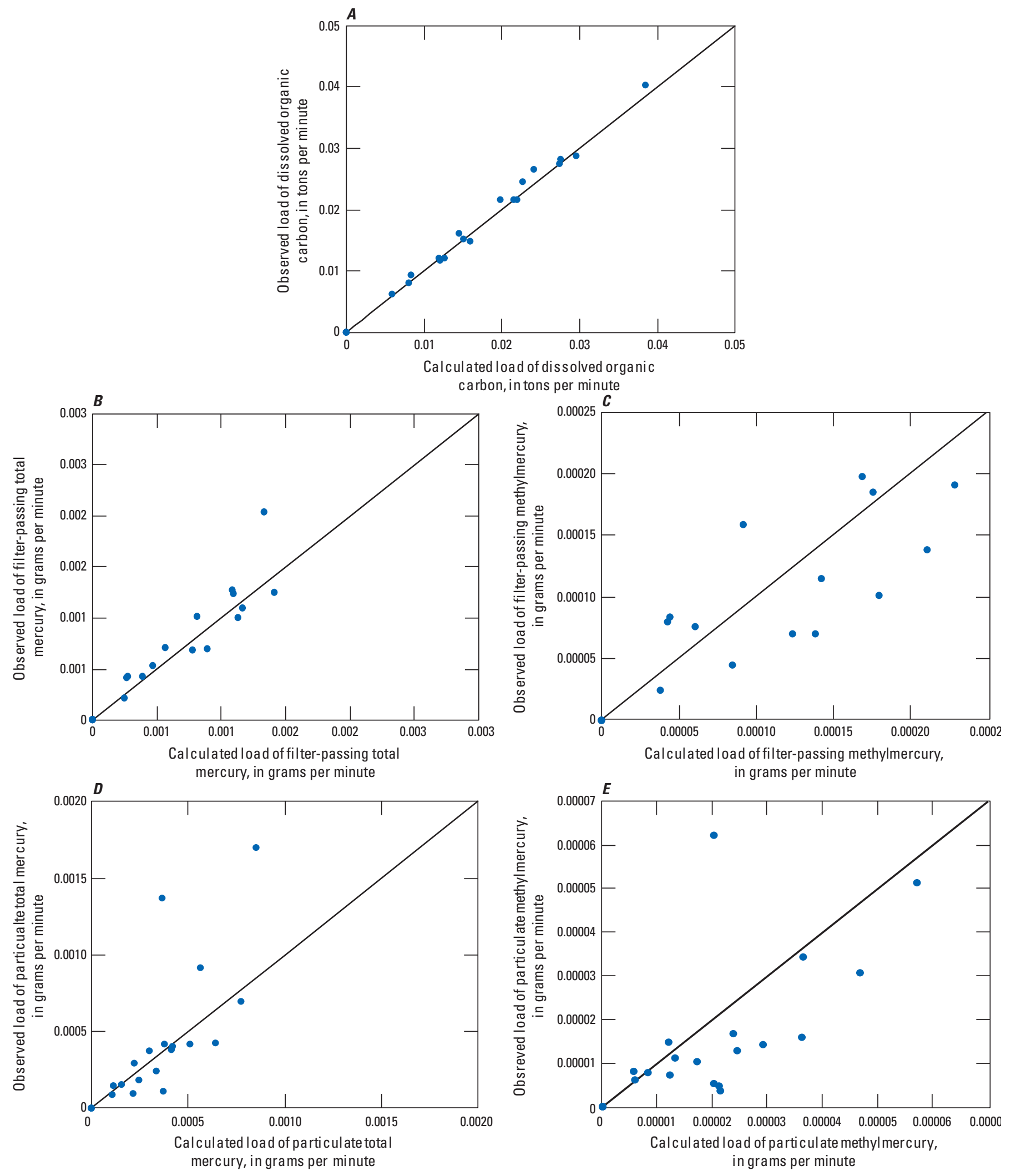

Figure 12. Comparisons between 1-minute loads calculated using observed concentrations and calculated concentrations. $A$, Dissolved organic carbon (DOC), $B$, Filter-passing total mercury (FTHg), C, filter-passing methylmercury (FMeHg), D, particulate total mercury (PTHg), and $E$, particulate methylmercury (PMeHg). The 1:1 line is shown in black. 


\section{Comparison of Traditional Discrete Sampling to Surrogate Approach}

An analysis was done to compare the surrogate model approach to traditional water-quality sampling approaches. For this exercise, the traditional water-quality sampling approach is defined as a single sample collected once a month that is assumed to represent the monthly mean concentration. The observed DOC concentrations were compared to the monthly mean surrogate calculated DOC concentrations, and the difference was greater than the maximum relative percent difference between concurrent observed and calculated concentrations (14 percent) during 22 percent of the study period, indicating that a single monthly sample of DOC is not always representative of the monthly conditions at the study area.
$\mathrm{Hg}$ loads were calculated using the surrogate model data and compared with loads calculated assuming the observed sample concentration was representative of the monthly mean (fig. 13). The latter approach used linear interpolations to estimate monthly concentrations for months when samples were not collected. In 2015, the $\mathrm{Hg}$ load predicted by the surrogate model is approximately 43 percent less than the load predicted solely on the basis of observed samples. Furthermore, the loads calculated from the surrogate model for 2014 and 2016 were 12 percent greater than and 19 percent less than the loads calculated using solely observed samples. These discrepancies highlight the limitations of using only discrete samples to determine constituent loads and indicate that the surrogate model approach potentially has advantages. Whether or not these advantages are worth the cost of continuous sensor monitoring needed for surrogate model development will depend on project objectives.

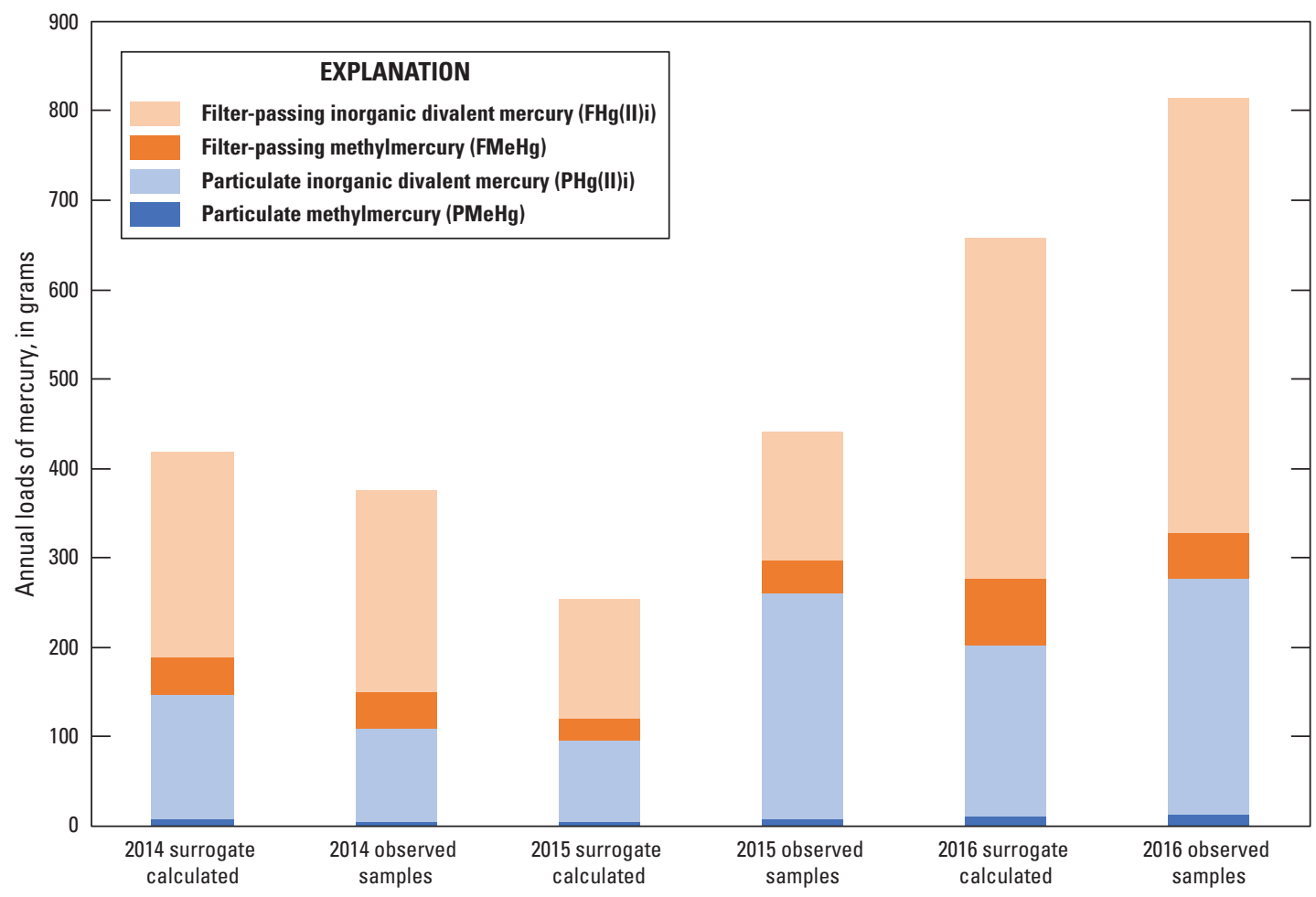

Figure 13. Annual loads of mercury, separated into fractions including particulate methylmercury (PMeHg), particulate inorganic divalent mercury (PHg[II]i), filter-passing methylmercury (FMeHg) and filter-passing inorganic divalent mercury (FHg[II]i)—calculated by the surrogate model approach and calculated using only observed samples. 


\section{Summary and Conclusions}

Mercury $(\mathrm{Hg})$ has been a contaminant of concern in the Florida Everglades and South Florida since the 1980s because of the risks associated with bioaccumulation of methylmercury (MeHg) to both humans and wildlife. In aquatic systems, inorganic divalent mercury ( $\mathrm{Hg}[\mathrm{II}] \mathrm{i})$ can be converted to $\mathrm{MeHg}$, the form of $\mathrm{Hg}$ that bioaccumulates in food webs. Dissolved organic carbon (DOC) is recognized as an important aqueous constituent that influences the transport and bioavailability of $\mathrm{Hg}$ to methylating organisms. This report summarizes the concentrations and loads, from late September 2013 to early April 2017, for total $\mathrm{Hg}$ and $\mathrm{MeHg}$ (filter-passing and particulate) and for DOC discharged through control structure S-12D, one of several structures that regulate freshwater flow to Everglades National Park.

Linear regression analyses were used to develop five site-specific models that were than used as surrogates to calculate concentrations and loads of DOC, filter-passing total mercury (FTHg), filter-passing methylmercury (FMeHg), particulate total mercury (PTHg), and particulate methylmercury (PMeHg) passing through S-12D at 15-minute intervals. To calculate DOC, the model inputs were fDOM and specific conductance. Temperature and fDOM were used as the model inputs to calculate FTHg and FMeHg. Turbidity was used as the sole model input to calculate PTHg and PMeHg.

Good agreement was demonstrated between observed and calculated concentrations of DOC at S-12D. The surrogate model revealed that concentrations varied over short periods of time. The annual loads of DOC to Everglades National Park through S-12D ranged from 3,950 tons in calendar year 2015 to 10,900 tons in calendar year 2016. Monthly mean loads of DOC increased with increasing flow.

Reasonable agreement also was demonstrated between observed and calculated concentrations of FTHg, FMeHg, $\mathrm{PHg}$, and PMeHg at S-12D. In general, FTHg and FMeHg concentrations were lower during periods of reduced flow and higher during periods of increased flow. For calculated daily loads of THg (filter-passing and particulate), FTHg constituted a greater portion than PTHg, though during early periods of high flow or immediately following gate openings at S-12D, the proportion of PTHg to FTHg increased. $\mathrm{MeHg}$ was present predominantly in the filter-passing fraction compared to the particulate fraction. The annual loads of total $\mathrm{Hg}$ (filter-passing and particulate) ranged from 254 grams in 2015 to 658 grams in 2016 . Interannual variability in the annual loads of $\mathrm{Hg}$ were attributed to differences in flow through S-12D over the years of this study. Mercury transported into Everglades National Park through S-12D is primarily $\mathrm{Hg}(\mathrm{II}) \mathrm{i}$. Methylmercury was approximately 6 percent of the total particulate fraction of $\mathrm{Hg}$ and 16 percent of the filter-passing fraction.

Information presented herein provides the first assessment of DOC and $\mathrm{Hg}$ concentrations and loads to Everglades National Park through control structure S-12D on the basis of continuous in situ measurements and documenting the changes in constituent concentrations and loads at a higher resolution than was previously possible. The models and load calculations allow for the evaluation of changes in DOC and $\mathrm{Hg}$ loads to the park in response to upgradient water and land management efforts. Analysis showed flow variability is more important than concentration variability for the purpose of computing loads. Furthermore, these data may inform the relative contribution of watershed source of $\mathrm{Hg}$ to Everglades National Park versus direct atmospheric deposition of $\mathrm{Hg}$.

\section{Acknowledgments}

Gratitude goes to the Greater Everglades Priority Ecosystem Studies Program for providing the funding necessary to carry out the work described here. We also thank Sara Breitmeyer (U.S. Geological Survey) and the U.S. Geological Survey Mercury Research Laboratory for assistance with measurements of dissolved organic carbon and mercury fractions, respectively.

\section{References Cited}

Abtew, W., and Ciuca, V., 2017, South Florida hydrology and water management, chap. 2, of 2017 South Florida environmental report. Volume 1-The South Florida environment: South Florida Water Management District report, accessed December 10, 2018, at https://apps.sfwmd.gov/sfwmd/SFER/2017_sfer_final/v1/ chapters/v1_ch2.pdf.

Aiken, G.R., 1992, Chloride interference in the analysis of dissolved organic carbon by the wet oxidation method: Environmental Science \& Technology, v. 26, no. 12 , p. 2435-2439, accessed December 1, 2018, at https://pubs.acs.org/doi/pdf/10.1021/es00036a015.

Aiken, G.R., Gilmour, C.C., Krabbenhoft, D.P., and Orem, W., 2011, Dissolved organic matter in the Florida Everglades-Implications for ecosystem restoration: Critical Reviews in Environmental Science and Technology, v. 41, sup1, p. 217-248, accessed December 1, 2018, at https://www.tandfonline.com/doi/full/10.1080/ 10643389.2010 .530934 .

Axelrad, D.M., Lange, T., Atkeson, T.D., and Gabriel, M.C., 2009, Mercury and sulfur monitoring research and environmental assessment in South Florida, chap. 3B of 2009 South Florida environmental report. Volume IThe South Florida environment: West Palm Beach, Fla., South Florida Water Management District report, accessed December 4, 2019, at https://my.sfwmd.gov/portal/page/ portal/pg_grp_sfwmd_sfer/portlet_sfer/tab2236041/ 2009report/report/v1/chapters/v1_ch3b.pdf. 
Bergamaschi, B.A., Fleck, J.A., Downing, B.D., Boss, E., Pellerin, B., Ganju, N.K., Schoellhamer, D.H., Byington, A., A., Heim, W.A., Stephenson, M., and Fujii, R., 2011, Methylmercury dynamics in a tidal wetland quantified using in situ optical measurements: Limnology and Oceanography, v. 56, no. 4, p. 1355-1371, accessed October 1, 2017, at https://doi.org/10.4319/ lo.2011.56.4.1355.

Bergamaschi, B.A., Fleck, J.A., Downing, B.D., Boss, E., Pellerin, B.A., Ganju, N.K., Schoellhamer, D.H., Byington, A.A., Heim, W.A., Stephenson, M., and Fujii, R., 2012a, Mercury dynamics in a San Francisco estuary tidal wetland-Assessing dynamics using in situ measurements: Estuaries and Coasts, v. 35, no. 4, p. 1036-1048, accessed October 1, 2017, at https://link.springer.com/article/ 10.1007/s12237-012-9501-3.

Bergamaschi, B.A., Krabbenhoft, D.P., Aiken, G.R., Patino, E., Rumbold, D.G., and Orem, W.H., 2012b, Tidally driven export of dissolved organic carbon, total mercury, and methylmercury from a mangrove-dominated estuary: Environmental Science \& Technology, v. 46, no. 3, p. 1371-1378, accessed October 1, 2017, at https://doi.org/ $10.1021 /$ es2029137.

Booth, A.B., 2020, Calculated mercury and carbon concentrations, USGS station 254543080405401: Tamiami Canal at S-12D Near Miami, Florida, 2013-2017: U.S. Geological Survey data release, https://doi.org/10.5066/P99L01UW.

Clescrei, L.S., Eaton, A.D., Greenburg, A.E., and Franson, M.A.H., 1998, Standard methods for the examination of water and wastewater Method $5310 \mathrm{~B}$; total organic carbon (TOC), high temperature combustion method (20th ed.): Washington D.C., American Public Health Association, p. 21-23, accessed April 19, 2019, at https://www.standardmethods.org/doi/suppl/10.2105/ SMWW.2882.104/suppl_file/5310+\%282000\%29.pdf.

Coburn, S., Dix, B., Edgerton, E., Holmes, C.D., Kinnison, D., Liang, Q., ter Schure, A., Wang, S., and Volkamer, R., 2016, Mercury oxidation from bromin chemistry in the free troposphere over the southeastern US: Atmospheric Chemistry and Physics, v. 16, no. 6, p. 3743-3760, accessed April 19, 2019, at https://www.researchgate.net/publication/ 283767818_Mercury_oxidation_from_bromine_chemistry_ in_the_free_troposphere_over_the_southeastern_US.

Curtis, P.J., and Adams, H.E., 1995, Dissolved organic matter quantity and quality from freshwater and saltwater lakes in east-central Alberta: Biogeochemistry, v. 30, no. 1, p. 59-76, accessed April 24, 2019, at https://link.springer.com/article/10.1007/BF02181040.
Davis, B.E., 2005, A Guide to the proper selection and use of federally approved sediment and water-quality samplers: U.S. Geological Survey Open-File Report 2005-1097, accessed April 24, 2019, at https://pubs.usgs.gov/of/2005/ 1087/pdf/OFR_2005-1087.pdf.

DeWild, J.F., Olson, M.O., and Olund, S.D., 2002, Determination of methyl mercury by aqueous phase ethylation, followed by gas chromatographic separation with cold vapor atomic fluorescence detection: U.S. Geological Survey Open-File Report 01-445, accessed April 19, 2019, at https://pubs.usgs.gov/of/2001/ofr-01-445/.

DeWild, J.F., Olund, S.D., Olson, M.L., and Tate, M.T., 2004, Methods for the preparation and analysis of solids and suspended solids for methylmercury: U.S. Geological Survey Techniques and Methods, book 5A, chap. 7, accessed April 19, 2019, at https://pubs.usgs.gov/tm/ 2005/tm5A7/.

Domanski, M.M., Straub, T.D., and Landers, M.N., 2015, Surrogate analysis and index developer (SAID) tool (version 1.0, September 2015): U.S. Geological Survey Open-File Report 2015-1177, 38 p., accessed October 1, 2017, at https://doi.org/10.3133/ofr20151177.

Downing, B.D., Pellerin, B.A., Bergamaschi, B.A., Saraceno, J.F., and Kraus, T.E., 2012, Seeing the light-The effects of particles, dissolved materials, and temperature on in situ measurements of DOM fluorescence in rivers and streams: Limnology and Oceanography, Methods, v. 10, no. 10, p. 767-775, accessed April 19, 2019, at https://doi.org/ 10.4319/lom.2012.10.767.

Etheridge, A.B., 2015, Occurrence and transport of selected constituents in streams near the Stibnite mining area, Central Idaho, 2012-2014: U.S. Geological Survey Scientific Investigations Report 2015-5166, 47 p., accessed April 1, 2019, at https://doi.org/10.3133/sir20155166.

Gilmour, C.C., Podar, M., Bullock, A.L., Graham, A.M., Brown, S.D., Somenahally, A.C., Johs, A., Hurt, R.A., Jr., Bailey, K.L., and Elias, D.A., 2013, Mercury methylation by novel microorganisms from new environments: Environmental Science \& Technology, v. 47, no. 20, p. 11810-11820, accessed January 1, 2019, at https://pubs.acs.org/doi/10.1021/es403075t.

Guentzel, J.L., Landing, W.M., Gill, G.A., and Pollman, C.D., 1995, Atmospheric deposition of mercury in Florida - The fams project (1992-1994): Water, Air, and Soil Pollution, v. 80, no. 1-4, p. 393-402, accessed October 1, 2018, at https://link.springer.com/article/ 10.1007/BF01189689. 
Horowitz, A.J., 2009, Monitoring suspended sediments and associated chemical constituents in urban environmentsLessons from the city of Atlanta, Georgia, U.S.A, Water Quality Monitoring Program: Journal of Soils and Sediments, v. 9, no. 4, p. 342-363, accessed April 9, 2020, at https://link.springer.com/article/10.1007/s11368009-0092-y.

Mason, R.P., Reinfelder, J.R., and Morel, F.M.M., 1996, Uptake, toxicity and trophic transfer of mercury in a coastal diatom: Environmental Science and Technology, v. 30, p. 1835-1845, accessed October 1, 2018, at https://pubs.acs.org/doi/abs/10.1021/es950373d.

Monteiro, M.T., Oliveira, S.M., Luizao, F.J., Candido, L.A., Ishida, F.Y., and Tomasella, J., 2014, Dissolved organic carbon concentration and its relationship to electrical conductivity in the waters of a stream in forested Amazonian blackwater catchment: Plant Ecology \& Diversity, v. 7, no. 1-2, p. 205-213, accessed December 1, 2018, at https://doi.org/ 10.1080/17550874.2013.820223.

Olund, S.D., DeWild, J.F., Olson, M.L., and Tate, M.T., 2004, Methods for the preparation and analysis of solids and suspended solids for total mercury: U.S. Geological Survey Techniques and Methods, book 5A, chap. 8, 23 p., accessed October 1, 2017, at https://pubs.usgs.gov/tm/ 2005/tm5A8/.

Orem, W., Gilmour, C., Axelrad, D., Krabbenhoft, D., Scheidt, D., Kalla, P., McCormick, P., Gabriel, M., and Aiken, G., 2011, Sulfur in the South Florida ecosystem-Distribution, sources, biogeochemistry, impacts and management for restoration: Critical Reviews in Environmental Science and Technology, v. 41, sup1, p. 249-288, accessed November 15, 2018, at https://pubs.er.usgs.gov/publication/ 70036039 .

Pellerin, B.A., Saraceno, J.F., Shanley, J.B., Sebestyen, S.D., Aiken, G.R., Wollheim, G.R., and Bergamaschi, B.A., 2012, Taking the pulse of snowmelt-In situ sensors reveal seasonal, event and diurnal patterns of nitrate and dissolved organic matter variability in an upland forest stream: Biogeochemistry, v. 108, no. 1-3, p. 183-198, accessed January 8, 2019, at https://doi.org/10.1007/s10533011-9589-8.

Rantz, S.E., and others, 1982, Measurement and computation of streamflow-Volume 2. Computation of discharge: U.S. Geological Survey Water Supply Paper 2175, 284 p., accessed January 8, 2019, at https://pubs.er.usgs.gov/ publication/wsp2175.
Rasmussen, P.P., Gray, J.R., Glysson, G.D., and Ziegler, A.C., 2009, Guidelines and procedures for computing time-series suspended-sediment concentrations and loads from in-stream turbidity-sensor and streamflow data: U.S. Geological Survey Techniques and Methods, book 3, chap. C4, 53 p., accessed October 1, 2017, at https://doi.org/10.3133/tm3C4.

Rice, K.M., Walker, E.M., Wu, M., Gillette, C., and Blough, E.R., 2014, Environmental mercury and its toxic effects: Journal of Preventive Medicine and Public Health, v. 47, no. 2, p. 74-83, accessed October 1, 2017, at https://www.ncbi.nlm.nih.gov/pubmed/24744824.

Rumbold, D.G., Lange, T.R., Richard, D., DelPizzo, G., and Hass, N., 2018, Mercury biomagnification through food webs along a salinity gradient down-estuary from a biological hotspot: Estuarine, Coastal and Shelf Science, v. 200, p. 116-125, accessed October 1, 2018, at https://www.sciencedirect.com/science/article/abs/pii/ S0272771417305711.

Sanders, C.L., and Feaster, T.D., 2004, Computation of flow through water-control structures using program DAMFLO.2: U.S. Geological Survey Open-File Report 03-473, accessed October 1, 2017, at https://pubs.usgs.gov/of/2003/ ofr03473/pdf/ofr03-473.pdf.

Sauer, V.B., and Turnipseed, D.P., 2010, Stage measurement at gaging stations: U.S. Geological Survey Techniques and Methods, book 3, chap. A7, 45 p., accessed October 1, 2017, at https://doi.org/10.3133/tm3A7.

Schoellhamer, D.H., Mumley, T.E., and Leatherbarrow, J.E., 2007, Suspended sediment and sediment-associated contaminants in San Francisco Bay: Environmental Research, v. 105, no. 1, p. 119-131, accessed January 15, 2019, at https://pubs.er.usgs.gov/publication/70031507.

Spencer, R.G.M., Pellerin, B.A., Bergamaschi, B.A., Downing, B.D., Kraus, T.E.C., Smart, D.R., Dahlgren, R.A., and Hernes, P.J., 2007, Diurnal variability in riverine dissolved organic matter composition determined by in situ optical measurement in the San Joaquin River (California, USA): Hydrological Processes, v. 21, no. 23, p. 3181-3189, accessed October 1, 2018, at https://doi.org/10.1002/hyp.6887.

U.S. Army Corps of Engineers, 2012, Central and Southern Florida Project-Water control plan for Water Conservation Areas, Everglades National Park and ENP-South Dade conveyance system: U.S. Army Corps of Engineers report, accessed December 11, 2018, at http://w3.saj.usace.army.mil/h2o/lib/documents/ERTP/ 2012_WCAs_WCP.pdf. 
U.S. Environmental Protection Agency, [EPA], 2002, Method 1631, revision E-Mercury in water by oxidation, purge and trap, and cold vapor atomic fluorescence spectrometry: U.S. Environmental Protection Agency Report EPA-821-R99-05, accessed October 1, 2017, at https://www.epa.gov/sites/production/files/2015-08/ documents/method_1631e_2002.pdf.

U.S. Geological Survey, variously dated, National field manual for the collection of water-quality data, low level mercury: U.S. Geological Survey Techniques of WaterResources Investigations, book 9, chap. A5, section 5.6.4.B, accessed March 16, 2007, at https://water.usgs.gov/owq/ FieldManual/chapter5/pdf/5.6.4.B_v1.0.pdf.

U.S. Geological Survey, 2019, USGS water data for the Nation: U.S. Geological Survey National Water Information System database, accessed December 30, 2019, at https://doi.org/10.5066/F7P55KJN.
Wagner, R.J., Boulger, R.W., Jr., Oblinger, C.J., and Smith, B.A., 2006, Guidelines and standard procedures for continuous water-quality monitors - Station operation, record computation, and data reporting: U.S. Geological Survey Techniques and Methods, book 1, chap. D3, 51 p., accessed October 1, 2017, at https://pubs.usgs.gov/tm/2006/tm1D3/.

Weishaar, J., Aiken, G., Bergamaschi, B., Fram, M., Fujii, R., and Mopper, K., 2003, Evaluation of specific ultraviolet absorbance as an indicator of the chemical composition and reactivity of dissolved organic carbon: Environmental Science \& Technology, v. 37, no. 20, p. 4702-4708, accessed April 16, 2019, at https://pubs.acs.org/doi/10.1021/ es030360x.

Wentz, D.A., Brigham, M.E., Chasar, L.C., Lutz, M.A., and Krabbenhoft, D.P., 2014, Mercury in the Nation's streams - Levels, trends, and implications: U.S. Geological Survey Circular 1395, 90 p., accessed March 11, 2020, at https://doi.org/10.3133/cir1395. 
Appendixes 1-5. Available at https://doi.org/10.3133/ofr20201092

Appendix 1. Model Archive Summary for Dissolved Organic Carbon Concentrations at Station 254543080405401: Tamiami Canal at S-12D Near Miami, Florida

Appendix 2. Model Archive Summary for Filtered Mercury Concentrations at Station 254543080405401: Tamiami Canal at S-12D Near Miami, Florida

Appendix 3. Model Archive Summary for Filtered Methylmercury Concentrations at Station 254543080405401: Tamiami Canal at S-12D Near Miami, Florida

Appendix 4. Model Archive Summary for Particulate Mercury Concentrations at Station 254543080405401: Tamiami Canal at S-12D Near Miami, Florida

Appendix 5. Model Archive Summary for Particulate Methylmercury Concentrations at Station 254543080404401: Tamiami Canal at S-12D Near Miami, Florida 

For more information about this publication, contact

Director, Caribbean-Florida Water Science Center

U.S. Geological Survey

4446 Pet Lane, Suite 108

Lutz, FL 33559

(813) 498-5000

For additional information visit

https://www2.usgs.gov/water/caribbeanflorida/index.html

Publishing support provided by

Lafayette Publishing Service Center 


\section{II}

ISSN 2331-1258 (online) 